Article

\title{
Antifungal, Antitumoral and Antioxidant Potential of the Danube Delta Nymphaea alba Extracts
}

\author{
Mihaela Cudalbeanu ${ }^{1}$ (), Bianca Furdui ${ }^{1, *}$, Geta Cârâc ${ }^{1}$, Vasilica Barbu ${ }^{2}$, Alina Viorica Iancu ${ }^{3}$, \\ Fernanda Marques ${ }^{4}$, Jorge Humberto Leitão ${ }^{5}$ (D) , Sílvia Andreia Sousa ${ }^{5}$ (D) and \\ Rodica Mihaela Dinica ${ }^{1, *}$ \\ 1 Faculty of Sciences and Environment, Department of Chemistry Physical and Environment, \\ "Dunărea de Jos" University of Galati, 111 Domnească Street, 800201 Galati, Romania; \\ mihaela.cudalbeanu@ugal.ro (M.C.); geta.carac@ugal.ro (G.C.) \\ 2 Faculty of Food Science and Engineering, Department of Food Science, Food Engineering, Biotechnology \\ and Aquaculture, "Dunărea de Jos” University of Galati, 111 Domnească Street, 800201 Galati, Romania; \\ vasilica.barbu@ugal.ro \\ 3 Faculty of Medicine and Pharmacy, Department of Morphological and Functional Sciences, "Dunărea de Jos" \\ University of Galati, 800008 Romania, 47 Domnească Street, 8000008 Galati, Romania; \\ iancualina.2003@yahoo.com \\ 4 Departamento de Engenharia e Ciências Nucleares, Instituto Superior Técnico, University of Lisbon, \\ 2695-066 Bobadela, Portugal; fmarujo@ctn.tecnico.ulisboa.pt \\ 5 IBB-Institute of Bioengineering and Biosciences, Department of Bioengineering, Instituto Superior Técnico, \\ University of Lisbon, 1049-001 Lisbon, Portugal; jorgeleitao@tecnico.ulisboa.pt (J.H.L.); \\ sousasilvia@tecnico.ulisboa.pt (S.A.S.) \\ * Correspondence: bianca.furdui@ugal.ro (B.F.); rodica.dinica@ugal.ro (R.M.D.)
}

Received: 24 October 2019; Accepted: 18 December 2019; Published: 21 December 2019

\begin{abstract}
This study aimed to explore for the first time the biological properties such as antifungal, antitumoral and antioxidant of Danube Delta Nymphaea alba (N. alba) leaf and root methanolic extracts. The toxicity studies of $N$. alba extracts showed no inhibitory effect on wheat seed germination by evaluating the most sensitive physiological parameters (Germination \%, Germination index, Vigor index) and using confocal laser scanning microscopy images. The analyzed extracts were found to have high antifungal activity against Candida glabrata with MIC values of $1.717 \mu \mathrm{g} / \mathrm{mL}$ for leaf and $1.935 \mu \mathrm{g} / \mathrm{mL}$ for root. The antitumor activity of the both extracts against A2780/A2780cisR ovarian, LNCaP prostate and MCF-7 breast cancer cells was promising with $\mathrm{IC}_{50}$ values ranging from $23-274 \mu \mathrm{g} / \mathrm{mL}$ for leaf and 18-152 $\mu \mathrm{g} / \mathrm{mL}$ for root, and the combination of $N$. alba extracts with cisplatin showed a synergistic effect (coefficient of drug interaction $<1$ ). The antioxidant properties were assessed by $\beta$-carotene bleaching, ABTS and FRAP assays and cyclic voltammetry. Quercetin, the most prominent antioxidant, was quantified in very good yields by spectroelectrochemical assay.
\end{abstract}

Keywords: Nymphaea alba; antifungal activity; antitumor activity; antioxidant compounds; quercetin

\section{Introduction}

Plants are known to be rich sources of bioactive compounds [1]. Generally, plant bioactive compounds differ greatly in terms of their quality and quantity, depending on the plant or on the various constituent parts of the plant [2] and they have been widely assessed for their biological properties [3]. The bioactivity of plant extracts generally depends on the presence of polyphenols and flavonoids, carotenoids, terpenoids or chlorophyll [4]. Thus, new compounds from the plant world can play an important role in the development of more effective and safer drugs to combat infection diseases or cancer [5]. 
Fungal infections are another major cause of morbidity/mortality worldwide, with invasive fungal disease by members of the Candida genus the most common fungal infections in developed countries [6]. Presently available antifungal drug classes are few and some with high toxicity [7]. Furthermore, emerging resistance to the available antifungal drugs has been reported, in particular to azole and echinocandins, due to clinical and environment exposure [8]. Therefore, novel antifungal drugs or adjuvants that lower the quantities of antifungals to achieve eradication of infection with lower toxicity are urgently required [9].

Most active natural biological products are secondary metabolites with complex structures [10], and among them, compounds such as flavonoids, isoprenoids and alkaloids extracted from plants have been exploited for various illnesses due to their pharmacological properties [11], accounting for more than $30 \%$ of total antineoplastic drugs [12]. Polyphenols as gallic acid, ellagic acid, and flavonoids such as quercetin and apigenin contribute to antioxidant activity $[13,14]$, and they have gained importance as cytotoxic agents, also promoting apoptosis in cancer cells $[15,16]$.

Cancer treatment modalities involve surgery, chemotherapy and/or radiation therapy [11,17]. Most synthetic chemotherapeutic drugs with antitumor activity present high toxicity, usually associated with undesirable side-effects as is the case of cisplatin, a well-established anticancer drug with non-specific targeting that results in adverse effects and toxicity [18]. The demand for novel antitumor drugs presenting fewer side-effects and better therapeutic outcomes is a priority goal for cancer therapy [19]. Several plant-isolated antioxidant compounds have played an important role in cancer therapy and its prevention $[1,13,20]$. Although some treatment modalities have succeeded for many patients, cancer remains a major cause of death worldwide [11,21].

The literature shows that the potential synergy of natural compounds with therapeutic drugs may constitute an important strategy to fight against infections and tumors [2]. With all this in mind, we searched for antifungal, antitumoral, and antioxidant properties in extracts of Nymphaea alba (N. alba) (Figure 1), a member of a large Nymphaeaceae family of aquatic plants worldwide distributed and used for hundreds of years in traditional medicine. N. alba species contain antioxidant polyphenols, flavonoids and derived acids such as caffeic acid, ferulic acid, quinic acid, p-coumaric acid, gallic acid, quercetin, luteolin, orientin, catechin, epicatechin, naringin, naringenin and rutin phytochemicals that have shown inhibitory effects on different phases of cell cycle and are also responsible for inducing apoptosis by regulating the expression of different apoptotic signaling pathways [22-24]. Flower extracts of the Nymphaea genus have been reported to have antineoplastic effects in different types of cancer, including leukemia, lung cancer, colon cancer and prostate cancer [25]. However, there is little evidence of their antineoplastic effects on ovarian and breast cancer cells.

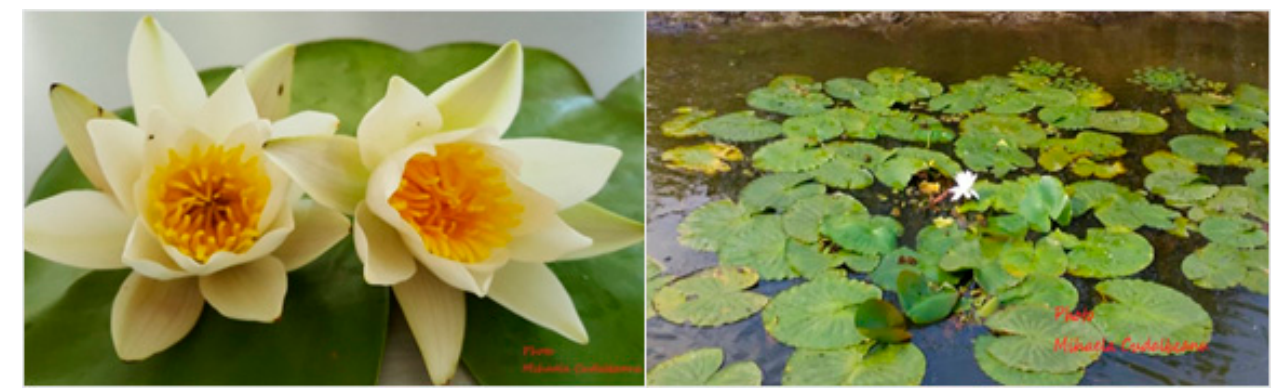

Figure 1. Nymphaea alba.

Many phytochemical compounds and various secondary metabolites, such as amino acids, sterols, alkaloids, saponins, tannins, and flavonoids, have been isolated from the Nymphaea genus [26,27]. The literature on Nymphaea genus has focused on acute and chronic toxicity of phytochemical compounds from crude extracts and their antibacterial, antioxidant, antihelmintic and antidiabetic potential [27]. There are data reports about the medicinal properties of the Nymphaea genus, namely 
the antibacterial potential against human pathogens and plant bacteria, but there is still little scientific evidence for the use of this plant commercially or in a more effective way [26].

The biological evaluation of Nymphaea alba has been centered mainly on its antioxidant properties and modulation of the oxidative stress due to its high phenolic content. Many studies have shown that extracts, rich in antioxidants such as polyphenols, have also antimicrobial activities against various pathogens [28] and also against a multitude of opportunistic invaders, including fungi of the Candida species $[28,29]$. In addition, these antioxidants can help prevent disease by reducing oxidative stress in the human body. Regarding the anticancer properties, phenolic compounds can induce cancer cell death and suppress cancer cell progression in a dose-dependent manner. In fact, at low doses these compounds could suppress cellular oxidative stress and cancer cell migration but at higher doses could act as pro-oxidants and anticancer cell proliferation agents [30-32].

Herein, we report some relevant biological properties of $N$. alba extracts species from Danube Delta Biosphere Reserve of Romania. The study namely comprises the antioxidant activities of N. alba extracts assessed by $\beta$-carotene bleaching, ABTS assays, FRAP assays and cyclic voltammetry, the toxicity activity towards wheat seed germination, the antifungal properties against Candida glabrata strain, and the cytotoxic activity on ovarian, breast and prostate cancer cells.

\section{Results}

\subsection{Toxicity Effects on Wheat Seed Germination}

Wheat (Triticum aestivum L.) seed germination has been used as a very sensitive model to measure the toxicity of different compounds [33]. Considering the literature data, we investigated the toxicity of the N. alba leaf and root extracts on wheat seed germination in order to evaluate the hazardous potential of these extracts in case of potential uses in the pharmaceutical industry. The most sensitive physiological parameters evaluated were selected based on the literature data. Higher plants are suitable for toxicity studies, as they are recognized as excellent indicators of cytogenetic and mutagenic effects of chemicals. The germination tests are very simple, not very time consuming, and cheap, and could therefore be an ideal method for testing the toxicity of chemicals $[34,35]$.

The results revealed that the application of the different concentrations of N. alba extracts had no toxic influence on seed germination. Compared to the control, the shoot and root of the wheat germinated seeds with different concentrations of N. alba extracts showed a slightly greater size, which may be due to the stimulant action of the bioactive compounds (Table 1).

Table 1. Evaluation of different physiological parameters of wheat seed germination on treatment with N. alba extracts. Results are expressed as mean values \pm standard deviation.

\begin{tabular}{|c|c|c|c|c|c|c|c|c|c|}
\hline \multirow{3}{*}{$\begin{array}{l}\text { Physiological } \\
\text { Parameters * }\end{array}$} & \multicolumn{8}{|c|}{ Concentration of the $N$. alba Extracts $(\mu \mathrm{g} / \mathrm{mL})$} & \multirow{3}{*}{ Control } \\
\hline & \multicolumn{4}{|c|}{ Leaf } & \multicolumn{4}{|c|}{ Root } & \\
\hline & 10 & 100 & 500 & 1000 & 10 & 100 & 500 & 1000 & \\
\hline $\mathrm{G} \%$ & $\begin{array}{c}94.2 \pm \\
0.24\end{array}$ & $\begin{array}{c}94.6 \pm \\
0.40\end{array}$ & $\begin{array}{c}95.9 \pm \\
0.91\end{array}$ & $\begin{array}{c}97.4 \pm \\
0.50 \\
\end{array}$ & $\begin{array}{c}94.7 \pm \\
0.52 \\
\end{array}$ & $\begin{array}{l}96 \pm \\
0.37\end{array}$ & $\begin{array}{l}96 \pm \\
0.15\end{array}$ & $\begin{array}{c}97.4 \pm \\
1.00\end{array}$ & $\begin{array}{c}100 \pm \\
0.00\end{array}$ \\
\hline RRG \% & $\begin{array}{c}84.60 \pm \\
1.20\end{array}$ & $\begin{array}{c}101.13 \pm \\
0.87\end{array}$ & $\begin{array}{c}103.43 \pm \\
1.13\end{array}$ & $\begin{array}{c}103.55 \pm \\
0.97\end{array}$ & $\begin{array}{c}69.09 \pm \\
0.73\end{array}$ & $\begin{array}{c}91.76 \pm \\
1.00\end{array}$ & $\begin{array}{c}94.55 \pm \\
0.76\end{array}$ & $\begin{array}{c}100.07 \pm \\
0.45\end{array}$ & $\begin{array}{c}100 \pm \\
0.00\end{array}$ \\
\hline GI & $\begin{array}{l}1.1 \pm \\
0.10\end{array}$ & $\begin{array}{c}0.9 \pm \\
0.20\end{array}$ & $\begin{array}{c}0.9 \pm \\
0.25\end{array}$ & $\begin{array}{c}0.9 \pm \\
0.14\end{array}$ & $\begin{array}{c}1.4 \pm \\
0.10\end{array}$ & $\begin{array}{c}1.0 \pm \\
0.21\end{array}$ & $\begin{array}{c}1.0 \pm \\
0.50\end{array}$ & $\begin{array}{c}1.0 \pm \\
0.45\end{array}$ & $\begin{array}{c}1.0 \pm \\
0.00\end{array}$ \\
\hline VI & $\begin{array}{c}120.2 \pm \\
0.43\end{array}$ & $\begin{array}{c}146.2 \pm \\
0.35\end{array}$ & $\begin{array}{c}117.9 \pm \\
0.10\end{array}$ & $\begin{array}{c}113.8 \pm \\
0.10\end{array}$ & $\begin{array}{c}89.5 \pm \\
0.24\end{array}$ & $\begin{array}{c}137.6 \pm \\
0.17\end{array}$ & $\begin{array}{c}92.9 \pm \\
0.24\end{array}$ & $\begin{array}{c}123.7 \pm \\
0.13\end{array}$ & $\begin{array}{c}66.6 \pm \\
0.14\end{array}$ \\
\hline TI & $\begin{array}{c}0.8 \pm \\
0.12\end{array}$ & $\begin{array}{c}0.6 \pm \\
0.12\end{array}$ & $\begin{array}{c}0.5 \pm \\
0.24\end{array}$ & $\begin{array}{c}0.6 \pm \\
0.10\end{array}$ & $\begin{array}{c}0.7 \pm \\
0.43\end{array}$ & $\begin{array}{c}0.5 \pm \\
0.12\end{array}$ & $\begin{array}{c}0.5 \pm \\
0.11\end{array}$ & $\begin{array}{c}0.8 \pm \\
0.10\end{array}$ & $\begin{array}{l}1.0+ \\
0.00\end{array}$ \\
\hline
\end{tabular}

* G\% - germination percentage; RRG\%—relative root growth percentage; GI-germination index; VI-vigor index; TI-tolerance index. 
Also, the sections through the stems of the seedlings of the wheat germinated seeds with both extracts indicated healthy plant tissues, without morphological and structural alterations, as was observed by confocal laser scanning microscopy (Figures 2-4). Cellular differentiation was not influenced by $N$. alba leaf and root extracts used in the experiments. From microscopic analysis in all samples, normal structures can be observed, including: the monolayered epidermis, the cortical parenchyma with isodiametric cells, the assimilator tissue rich in chloroplasts, the pericycle separating the cortical parenchyma from the central stele (Figure $4 \mathrm{~d}$ ), and the specific vascular tissue components (in blue): xylem (X) (Figure 2a, Figure 3a,d and Figure 4a), or phloem (Ph) (Figure 4a). The confocal analysis from the experimental variants showed normal differentiated epidermal cell types such as numerous trichomes or hairs $(\mathrm{H})$ or stomata type Zea (S) (in blue), indicating that the N. alba leaf and root extracts enabled or even facilitated the differentiation of these structures. The only changes reported at higher concentrations of $N$. alba leaf and root extracts were the tendency to elongate the cells, which become easy prosenchymatous, with a long side of $46.85 \mu \mathrm{m}$ (Figure 3c) or of $82.5 \mu \mathrm{m}$ (Figure 4c). The presence of a greater number of plasmodesmata (see the arrows in Figures $3 \mathrm{~b}$ and $4 \mathrm{c}$ ) allow a better intercellular communication, probably due to interaction of plant tissue with phytochemical compounds from N. alba extracts. When a concentration of $1000 \mu \mathrm{g} / \mathrm{mL}$ of the N. alba root extract (Figure $4 \mathrm{~d}$ ) was used, corpuscles (see the red arrows) with autofluorescence in the range 570-650 nm were identified in the cytoplasm of parenchyma cells, which might result from the metabolism/assimilation of biologically active compounds from extracts used for seed germination.

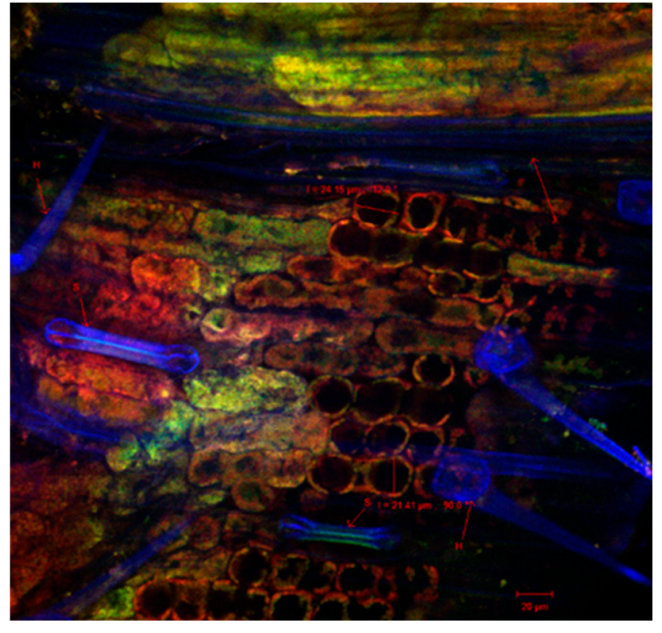

(a)

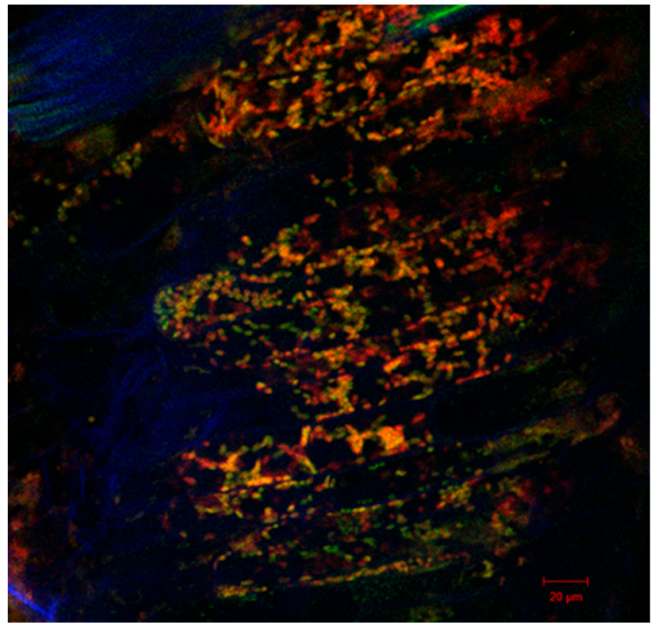

(b)

Figure 2. Confocal laser scanning microscopy images of the wheat sprout sections variants: (a) ultrapure water control samples; and (b) methanol control samples. 


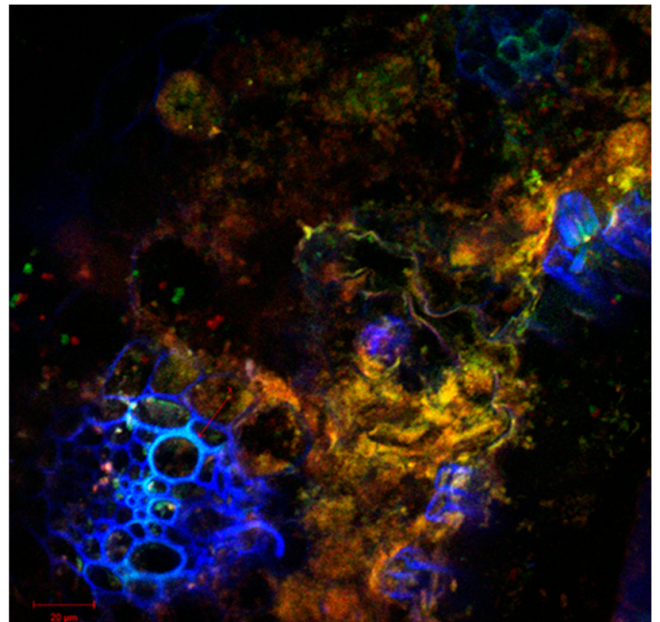

(a)

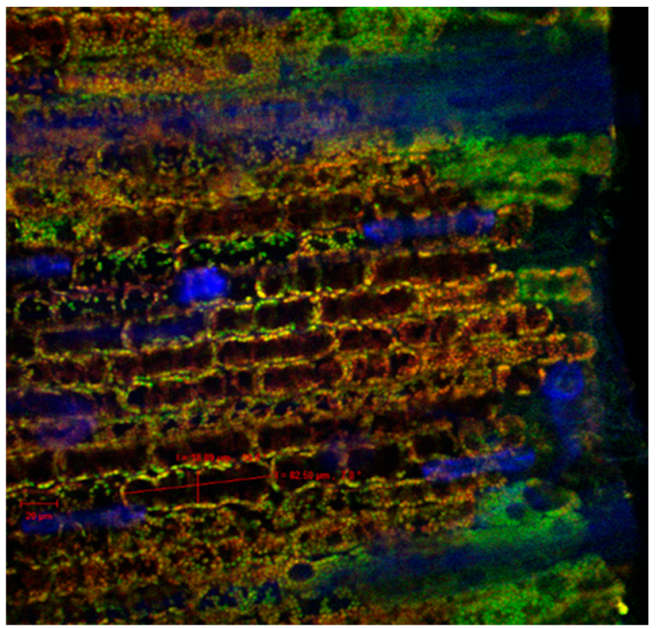

(c)

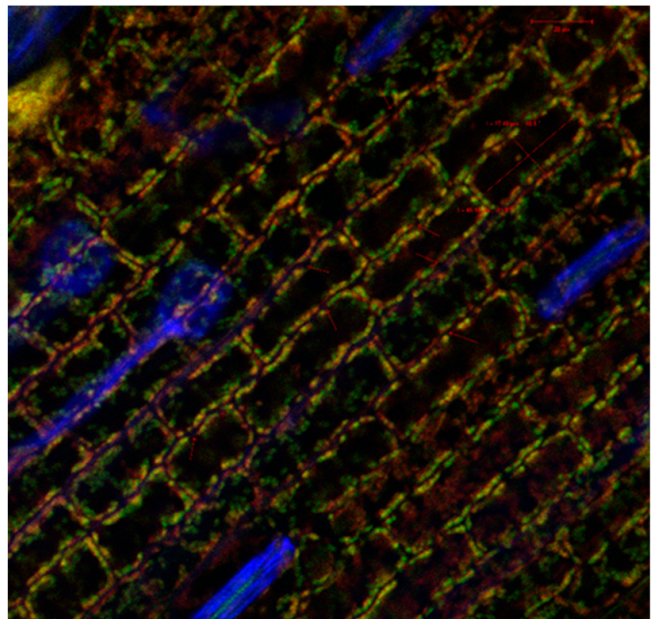

(b)

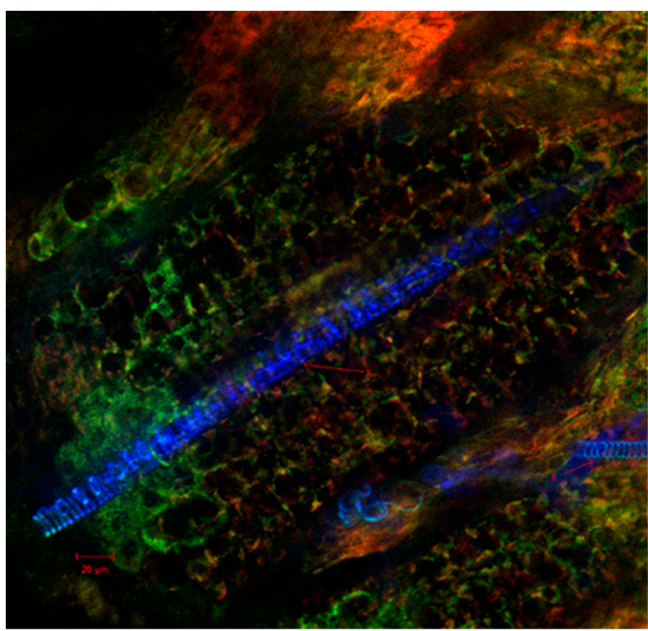

(d)

Figure 3. Confocal laser scanning microscopy images of the wheat shoot sections variants of the N. alba leaf extract treatments: (a) $10 \mu \mathrm{g} / \mathrm{mL}$, (b) $100 \mu \mathrm{g} / \mathrm{mL}$, (c) $500 \mu \mathrm{g} / \mathrm{mL}$, and (d) $1000 \mu \mathrm{g} / \mathrm{mL}$.

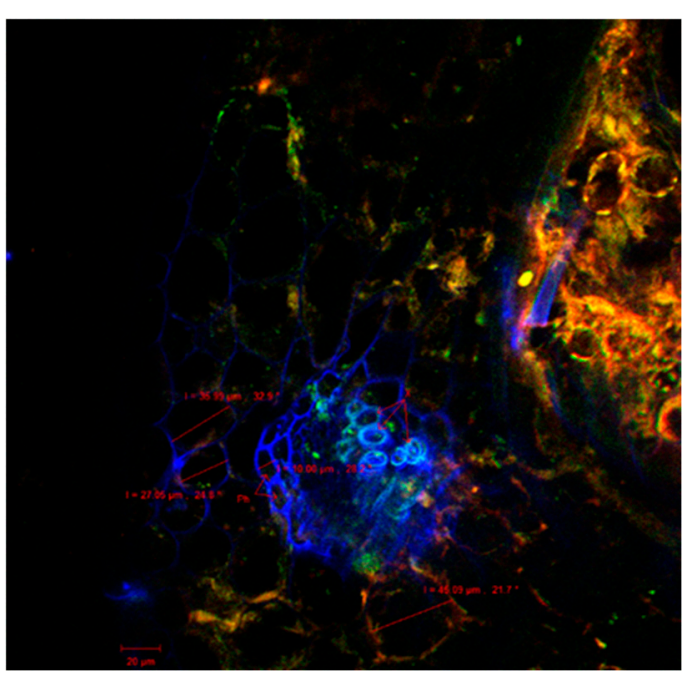

(a)

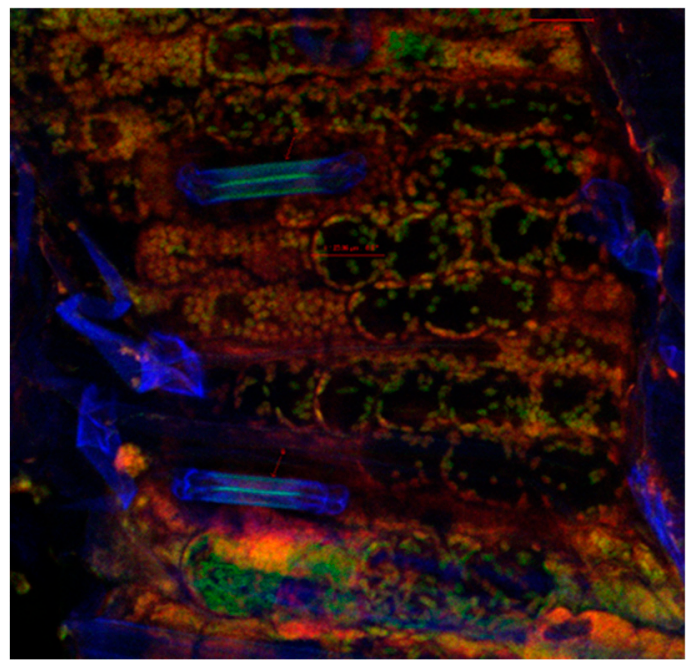

(b)

Figure 4. Cont. 


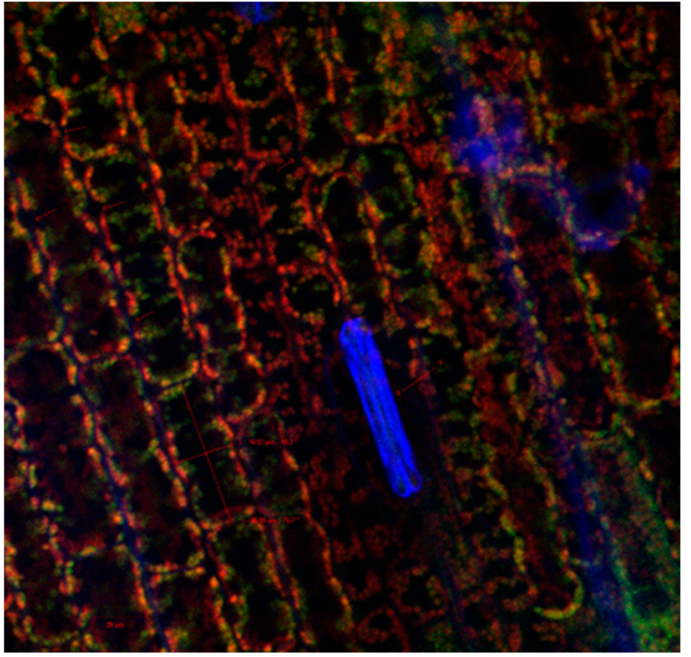

(c)

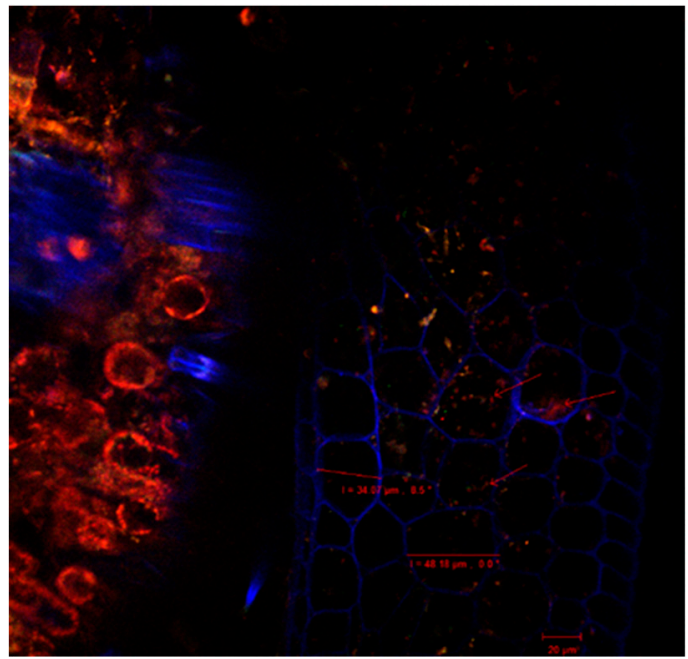

(d)

Figure 4. Confocal laser scanning microscopy images of the wheat shoot sections variants of the N. alba root extract treatments: (a) $10 \mu \mathrm{g} / \mathrm{mL}$, (b) $100 \mu \mathrm{g} / \mathrm{mL}$, (c) $500 \mu \mathrm{g} / \mathrm{mL}$, and (d) $1000 \mu \mathrm{g} / \mathrm{mL}$.

\subsection{Antifungal Activity}

Compounds that have both anticancer and antimicrobial activity are promising therapeutic agents due to their potential to diminish the occurrence of opportunistic fungal infections often associated with chemotherapy [36]. The antifungal activity (MIC) was evaluated in vitro against 4 fungal strains C. glabrata CBS 138, C. albicans SC 5134, C. parapsilosis ATCC22019 and C. tropicalis ATCC750 using N. alba extracts with concentrations between 0.23 and $2000 \mu \mathrm{g} / \mathrm{mL}$, and fluconazole (FLC) as control with concentrations between 0.23 and $250 \mu \mathrm{g} / \mathrm{mL}$ (Figure 5). The N. alba leaf and root extracts were found to be active against C. glabrata, with MIC values of 1.717 and $1.935 \mu \mathrm{g} / \mathrm{mL}$ for leaf and root extracts, and 0.7639 for FLC, respectively [37]. The obtained results showed that the action of the extracts was specific for C. glabrata, having no action on the other Candida strains tested.

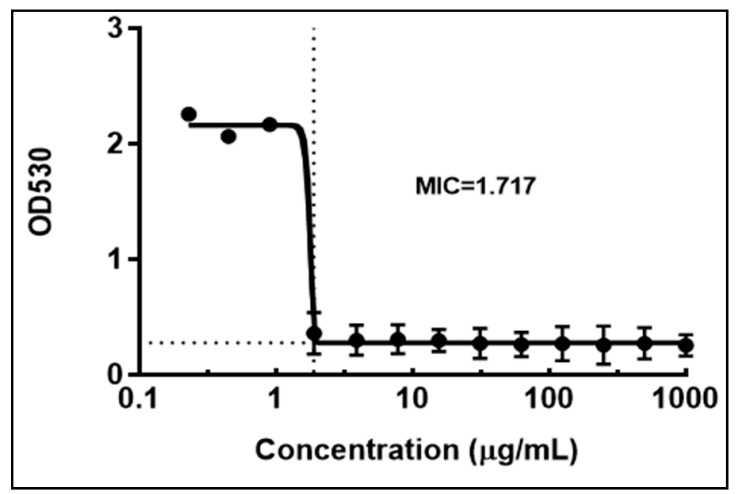

(a)

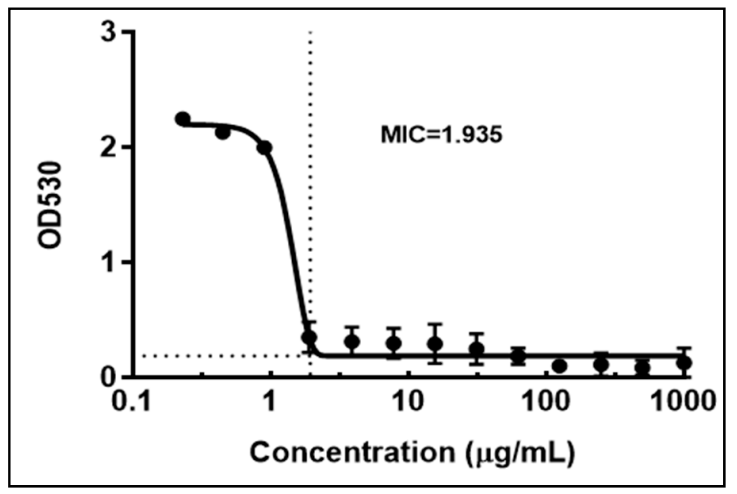

(b)

Figure 5. Cont. 


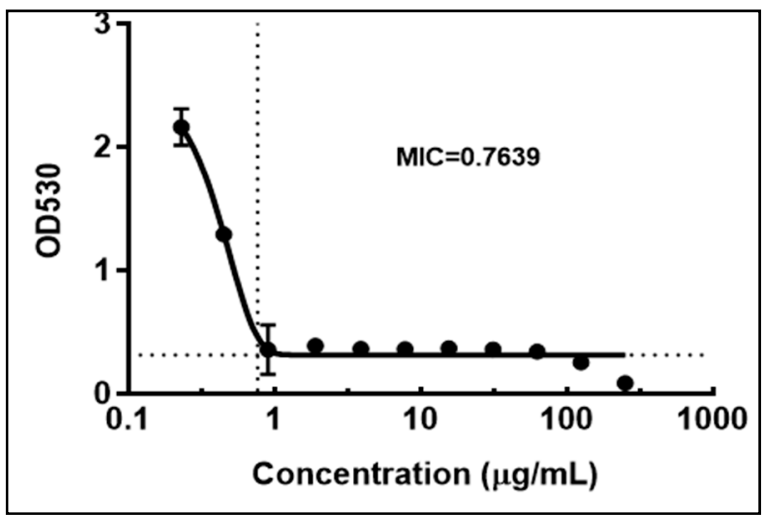

(c)

Figure 5. The MIC of the N. alba leaf (a) and root (b) extracts and fluconazole (c) against C. glabrata CBS 138.

C. glabrata is phylogenetically, genetically and phenotypically distinct from the other pathogenic yeast species like C. albicans, C. parapsilosis and C. tropicalis [38]. The MIC values of the N. alba leaf and root extracts against C. albicans SC 5134, C. parapsilosis ATCC22019 and C. tropicalis ATCC750 were higher than $2000 \mu \mathrm{g} / \mathrm{mL}$.

The antifungal effects of the N. alba leaf and root extracts and FLC against C. glabrata CBS 138 strain were confirmed by viable count $(\mathrm{CFU} / \mathrm{mL})$. The results presented in Figure 6 show that both extracts exhibit fungistatic activity against C. glabrata CBS 138.

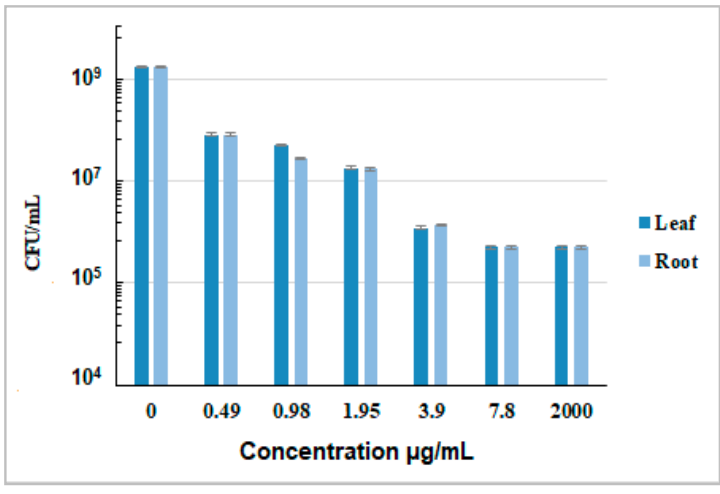

(a)

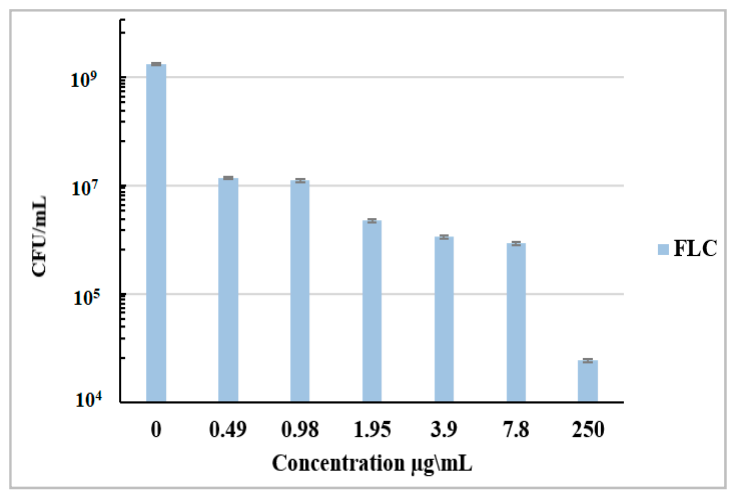

(b)

Figure 6. CFUs of C. glabrata CBS 138 strain, cultured in the presence of the indicated concentrations of the N. alba leaf and root (a) extracts and fluconazole (b).

The probable mechanism of action implicated in this type of compound, present in N. alba extracts, is the inhibition of efflux pumps, inhibition of fungal growth, reduction in number of yeast cells and germ tubes which ultimately results in induction of cell death or apoptosis [39].

\subsection{Cytotoxic Effects of N. alba Extracts on Normal and Tumor Cells}

Natural bioactive products can be considered prospective chemotherapeutic drugs due to their expected less toxic profile [15].

Compounds of plant origin have been shown to be effective against LNCaP prostate tumor cell growth [40]. However, the active species were identified mainly as fatty acid derivatives. A mixture of phytochemical compounds with a multitude of biological activities could have additional or synergistic 
effects against breast cancer [41]. In this regard, studies by Ashidi et al. [42] reported that the methanolic extracts of African medicinal plants have significant cytotoxicity on MCF7 breast cells, but also present some toxicity towards normal cells. Previous studies on phenolic constituents of Nymphaea alba extracts reported anti-proliferative activities and the ability to suppress cancer cell invasion but in different tumor models other than the MCF7 cells [31,32]. Aimvijarn et al. [32] reported that Nymphaea extract showed cytotoxicity to B16 melanoma cells with $\mathrm{IC}_{50}=814 \mu \mathrm{g} / \mathrm{mL}$. The extract at 800 and $1000 \mu \mathrm{g} / \mathrm{mL}$ demonstrated pro-oxidant activity related to cell apoptosis.

In our search for therapeutic agents based on plants, we evaluated the effect of the crude extracts from leaf and root of the $N$. alba species against tumor cell lines and on a normal cell line, using the MTT assay. The cytotoxicity of N. alba leaf and root extracts on the cells was assessed at various concentrations in the range $10-1000 \mu \mathrm{g} / \mathrm{mL}$. Upon treatment with both extracts at concentrations higher than $100 \mu \mathrm{g} / \mathrm{mL}$ for $24 \mathrm{~h}$, the cellular viability of the A2780 ovarian cancer cells was lower than $20 \%$ (Figure 7a). In the LNCaP prostate cells, the cytotoxicity of N. alba extracts was lower than that observed for the ovarian cells. However, the effect was dose dependent, and for concentrations higher than $500 \mu \mathrm{g} / \mathrm{mL}$, the root extract exhibited percentages of cellular viability of ca. $13-20 \%$ (Figure $7 \mathrm{~b}$ ). The cytotoxicity of N. alba leaf and root extracts towards the MCF7 cells was also analyzed. The results showed that N. alba extracts significantly inhibit the growth of MCF7 cancer cells at concentrations higher than $100 \mu \mathrm{g} / \mathrm{mL}$, in a similar mode to that observed for the ovarian cells (Figure 7c).

Our results indicated that in all cancer cell lines studied, the cytotoxicity was high, with $\mathrm{IC}_{50}$ values in the range of $23-274 \mu \mathrm{g} / \mathrm{mL}$ for the leaf and $18-152 \mu \mathrm{g} / \mathrm{mL}$ for the root (Table 2). Moreover, the root extracts had a slight tendency to be more cytotoxic, as can be observed in Figure 7.

Results presented herein encourage us to continue our research on the assumption that N. alba extracts contain promising therapeutic agents. Leaf and root extracts were also tested in the normal V79 cells at $10-1000 \mu \mathrm{g} / \mathrm{mL}$ to assess their cytotoxicity (Figure $7 \mathrm{~d}$ ). In these cells, a significant loss of cellular viability $(<50 \%)$ was observed only at concentrations higher than $500 \mu \mathrm{g} / \mathrm{mL}$, which indicate that the extracts have an important selectivity for cancer cells.

The cytotoxicity of the N. alba leaf and root extracts, due to the presence of bioactive compounds as corilagin, chlorogenic acid or caffeic acid can be explained on the one hand by inhibition of gene $\beta$-catenin and induction of genes as GSK-3 $\beta$, promoting the tumor cell apoptosis [23,24]. Flavonoids such as quercetin, naringin, naringenin, and apigenin inhibit or activate the different phases of cell cycle, and are also responsible for inducing apoptosis by regulating the expression of different apoptotic signaling pathways. Most of them show inhibitory effects on breast cancer by down-regulating estrogen receptor ER- $\alpha$ expression, inhibiting metastasis and proliferation, inducing caspase-mediated cell death and arresting the cell cycle $[23,24,43]$.
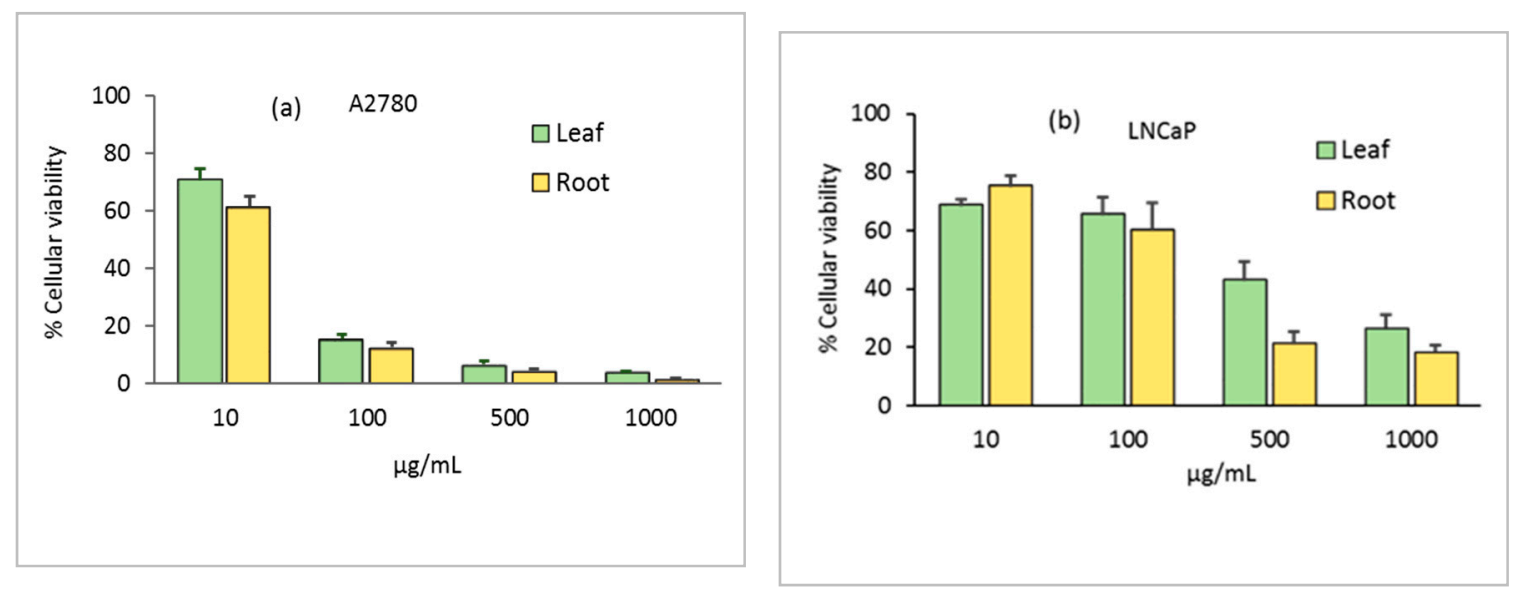

Figure 7. Cont. 

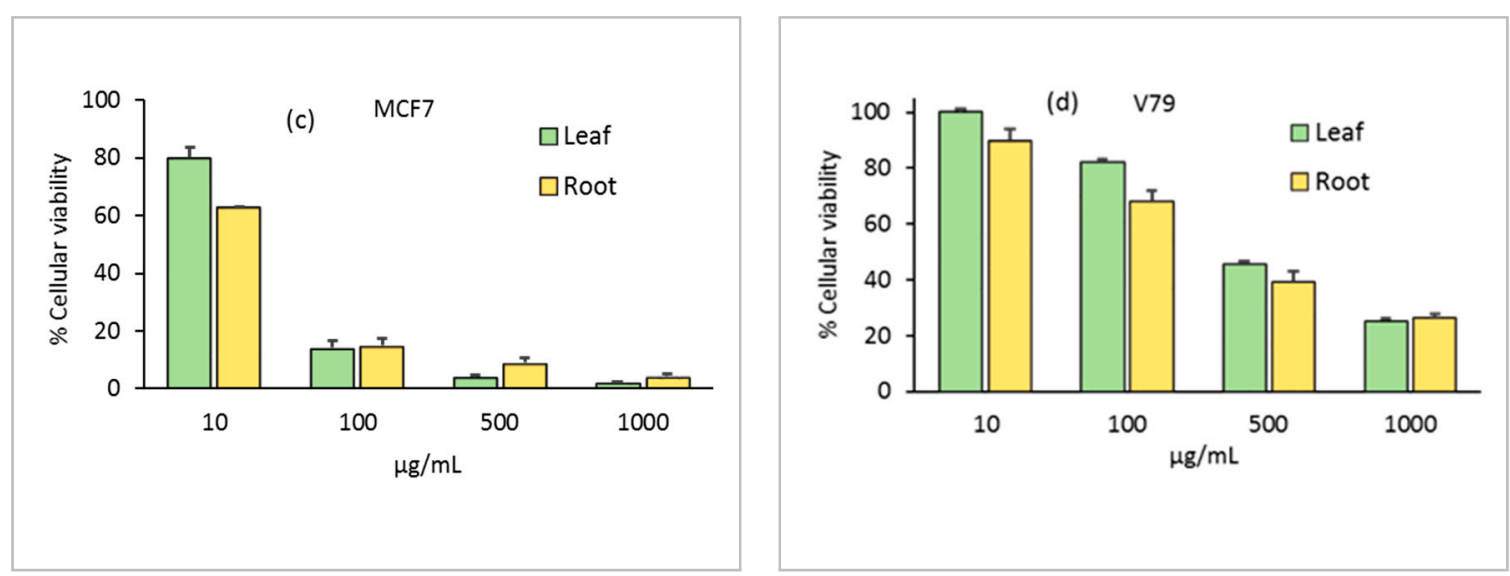

Figure 7. In vitro cytotoxicity assessment of N. alba leaf and root extracts on A2780 (a), LNCaP (b), MCF7 (c), and V79 (d) cell lines.

Table 2. $\mathrm{IC}_{50}$ values of $N$. alba extracts obtained after $24 \mathrm{~h}$ incubation. Data were obtained from dose-response curves using GraphPad Prism ver. 5. The results are expressed in $\mu \mathrm{g} / \mathrm{mL}$.

\begin{tabular}{ccccc}
\hline \multirow{2}{*}{ N. alba Extracts } & \multicolumn{4}{c}{ Tumor Cells * $^{*}$} \\
\cline { 2 - 5 } & V79 & A2780 & LNCaP & MCF-7 \\
\hline Leaf & $367 \pm 50$ & $23.2 \pm 3.0$ & $274 \pm 81$ & $25.4 \pm 5.9$ \\
Root & $281 \pm 59$ & $19.4 \pm 3.8$ & $152 \pm 47$ & $18.1 \pm 3.3$
\end{tabular}

* V79—lung fibroblasts normal cells; A2780—ovarian tumor cells; LNCaP—prostate tumor cells; MCF-7—tumor breast cells.

The $\mathrm{IC}_{50}$ value is a highly sensitive metric that is used to evaluate the results of drug response and drug potency. The $\mathrm{IC}_{50}$ values of the $N$. alba extracts against normal and cancer cell lines were calculated and are shown in Table 2. The results demonstrate that the N. alba leaf and root extracts have important cytotoxicity against A2780 and MCF7 cells, but exhibit negligible toxicity against the LNCaP and the V79 cell lines. Among the three cancer cell lines, the A2780 and MCF7 cell lines seem to be more sensitive to treatments with $N$. alba extracts than the LNCaP cell line. The two extracts are cell type selective and, most importantly, are less cytotoxic for normal cells. However, it is important to note that chemotherapeutic drugs act against cancer cells in a non-selective way, leading to adverse side effects and drug resistance. Combination therapies have proven to be promising alternatives for cancer therapy. As previously described [44], plant extracts contain several beneficial compounds that can target multiple pathways in cancer cells and can be more selective, sparing the normal cells. In addition, such combinations will enable a reduction in the dose of chemotherapy drugs.

\section{Combined Cytotoxic Effects of N. alba Extracts and Cisplatin on Ovarian Cell Lines}

The disadvantage of many cytotoxic agents is their high toxicity, which can produce considerably toxic side effects [15,45], not only on tumor cells but also on healthy cells [17]. Combined therapies in which both agents exhibit cytotoxicity result in dose-limited effects [46]. Cisplatin is one of the most effective chemotherapeutic agents used in the treatment of cancer, being a cytotoxic drug that affects the DNA [47]. Tumor resistance to cisplatin-based drugs is an obstacle in the treatment of, for instance, ovarian cancer. Novel approaches for treating ovarian cancer are the use of natural compounds with antineoplastic effects in combination with platinum-based drugs [48]. Two or more drugs that individually produce similar effects are expected to have greater effects when administered in combination. The combined effect can typically be described as synergistic, additive, indifferent or antagonistic. When the combined effect is greater than the individual effect of each drug, 
the combination is considered synergistic [49]. To reduce the toxic effects of drugs on normal tissues, combinations of lower doses of individual chemotherapeutic agents are required [50].

To evaluate the potential of the N. alba extracts by means of the above-mentioned combined therapy, we used the most effective extracts for the A2780 sensitive tumor cell line and extracts that do not show high cytotoxicity on normal cells. The N. alba leaf and root extracts were combined with cisplatin and were incubated with the A2780 and A2780cisR (cisplatin-resistant) cancer cell lines for $24 \mathrm{~h}$. Experiments were also performed using either cisplatin or N. alba extracts. To assess the in vitro cytotoxicity of N. alba extracts combined with cisplatin on the A2780 and A2780cisR cell line, a ratio of 1:10, cisplatin: extract was used. The extracts were used in concentrations of 10, 100, 500 and $1000 \mu \mathrm{g} / \mathrm{mL}$ and the cisplatin was used in concentrations of $1,10,20,50$, and $100 \mu \mathrm{g} / \mathrm{mL}$.

The experiments presented herein showed that adding N. alba extracts containing antioxidants permit reducing the concentration of cisplatin in order to decrease A2780/A2780ciR cell survival (Figure 8).

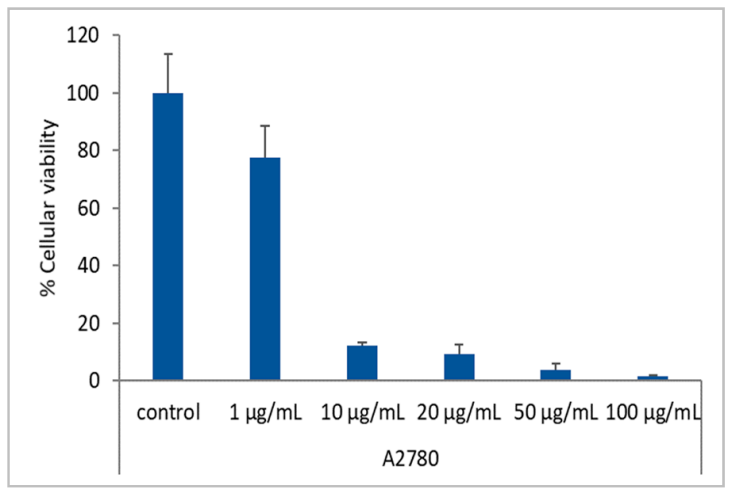

(a)

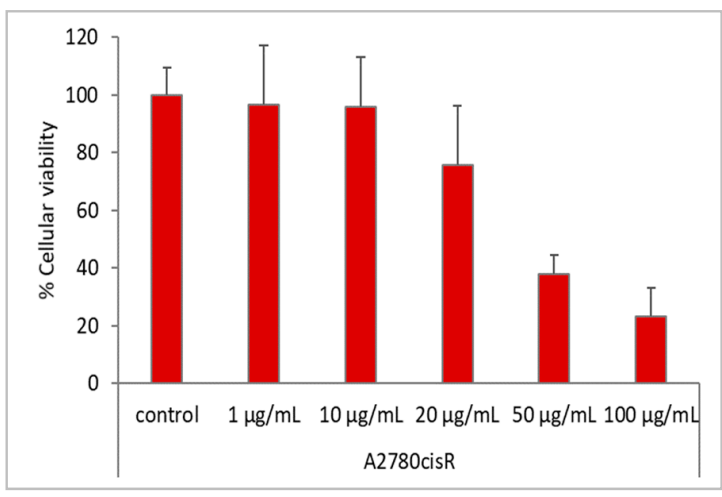

(b)

Figure 8. In vitro cytotoxicity assessment of cisplatin on $\mathrm{A} 2780$ (a) and $\mathrm{A} 2780$ cisR (b) cell lines. The $\mathrm{IC}_{50}$ values found using the GraphPad Prism software (ver. 5) were: A2780, $2.4 \pm 0.6 \mu \mathrm{g} / \mathrm{mL}(7.9 \mu \mathrm{M})$ and A2780cisR, $27 \pm 13 \mu \mathrm{g} / \mathrm{mL}(89 \mu \mathrm{M})$. Control = cells without treatment. Data are mean $\pm \mathrm{SD}$ of two independent experiments done with at least four replicates per condition.

The synergistic interactions between $N$. alba extracts and cisplatin were performed using the Chou method [51]. The combination index (CI) is given in Table 3. The obtained results indicate CI values ranging from 0.05 to 0.5 , suggesting a strong synergism in the growth inhibitory effect.

Table 3. Interaction between N. alba extracts and cisplatin on the A2780 and A2780cisR cancer cell lines. $\mathrm{Fa}$ is the fraction affected by dose; $\mathrm{CI}$ is the combination index.

\begin{tabular}{cccccc}
\hline \multicolumn{2}{c}{ Drug $(\mu \mathrm{g} / \mathrm{mL})$} & \multicolumn{2}{c}{ A2780 * } & \multicolumn{2}{c}{ A2780cisR * } \\
\hline Leaf & CisPt & Fa & CI & Fa & CI \\
\hline 1000 & 100 & 0.03 & 4.85 & 0.12 & 1.20 \\
500 & 50 & 0.01 & 1.03 & 0.10 & 0.44 \\
200 & 20 & 0.04 & 1.22 & 0.06 & 0.08 \\
100 & 10 & 0.02 & 0.35 & 0.07 & 0.05 \\
10 & 1 & 0.70 & 2.07 & 0.60 & 0.57 \\
\hline Root & CisPt & Fa & CI & Fa & CI \\
\hline 1000 & 100 & 0.10 & 12.59 & 0.25 & 2.81 \\
500 & 50 & 0.12 & 7.64 & 0.32 & 2.28 \\
200 & 20 & 0.09 & 2.25 & 0.17 & 0.30 \\
100 & 10 & 0.12 & 1.52 & 0.26 & 0.30 \\
10 & 1 & 0.69 & 2.25 & 0.89 & 10.03
\end{tabular}

* A2780—ovarian tumor cells; A2780cisR—ovarian tumor cisplatin-resistant cells. Cisplatin $=\mathrm{CisPt}$ 


\subsection{Antioxidant Capacities by Spectrophotometric Methods}

Different assays were used to determine the antioxidant activities of the N. alba leaf and root extracts, since antioxidant activities of different types of compounds involve different mechanisms, and a single assay is not conclusive. Thus, the antioxidant capacities of the N. alba leaf and root extracts were measured three times to test the evaluated reproducibility by a series of a microplate reader assays: $\beta$-carotene bleaching (BCB), ABTS, and FRAP. A lower $\mathrm{IC}_{50}$ value indicates increased antioxidant activity. Concentrations of the $N$. alba leaf and root extracts between $1-500 \mu \mathrm{g} / \mathrm{mL}$ were used for the antioxidant assays and their $\mathrm{IC}_{50}$ values. The obtained results for $\mathrm{BCB}, \mathrm{ABTS}$ and FRAP assays are shown in Table 4. All data were determined for the sample at a concentration of $500 \mu \mathrm{g} / \mathrm{mL}$.

Table 4. Antioxidant activity of N. alba extracts determined by BCB, ABTS and FRAP assays.

\begin{tabular}{|c|c|c|c|c|c|c|}
\hline \multirow{3}{*}{ Assay * } & \multicolumn{6}{|c|}{ N. alba Extracts } \\
\hline & \multicolumn{3}{|c|}{ Leaf } & \multicolumn{3}{|c|}{ Root } \\
\hline & $\begin{array}{l}\text { Inhibition } \\
\text { Percent (\%) }\end{array}$ & $\begin{array}{c}\mathrm{IC}_{50} \\
(\mu \mathrm{g} / \mathrm{mL})\end{array}$ & $\mu \mathrm{g}$ TEq/1 $\mathrm{g}$ & $\begin{array}{l}\text { Inhibition } \\
\text { Percent (\%) }\end{array}$ & $\begin{array}{c}\mathrm{IC}_{50} \\
(\mu \mathrm{g} / \mathrm{mL})\end{array}$ & $\mu \mathrm{g} T E q / 1 \mathrm{~g}$ \\
\hline BCB & $78.6 \pm 0.19$ & $33 \pm 0.86$ & $28,933 \pm 0.89$ & $90.1 \pm 0.90$ & $21 \pm 0.55$ & $79,371 \pm 1.03$ \\
\hline ABTS & $77.0 \pm 0.73$ & $12 \pm 0.11$ & $1309 \pm 0.33$ & $78.2 \pm 0.12$ & $10 \pm 0.10$ & $1950 \pm 0.41$ \\
\hline FRAP & $74.6 \pm 0.13$ & $30 \pm 0.25$ & $2245 \pm 0.67$ & $79.7 \pm 0.13$ & $13 \pm 0.15$ & $2407 \pm 0.98$ \\
\hline
\end{tabular}

* BCB- $\beta$-Carotene bleaching; ABTS-2,20-azinobis (3-ethylbenothiazoline-6-sulfonic acid) diammonium salt solution radical cation; FRAP-Ferric Reducing Antioxidant Power.

The $\beta$-carotene bleaching assay is used to measure the antioxidant activity for the plant extracts, especially to investigate lipophilic antioxidants. This assay measures the inhibition of autooxidation of the linoleic acid and $\beta$-carotene [52]. $\beta$-carotene forms a complex with linoleic acid and oxidizes it. The consumption of $\beta$-carotene causes the reduction of the bright yellow color of $\beta$-carotene. The presence of an antioxidant in the reaction mixture inhibits the consumption of $\beta$-carotene through inactivation of the linoleic acid free radicals, thus leading to the release of $\beta$-carotene from the complex with linoleic acid and the recovery of the yellow color of the reaction mixture. Results presented in Table 1 show a $78.6 \%$ inhibition of $\beta$-carotene consumption for the leaf extract, and $90.1 \%$ for the root extract. The antioxidant activity presented $\mathrm{IC}_{50}$ values as low as $33 \mu \mathrm{g} / \mathrm{mL}$ for the leaf extract and $21 \mu \mathrm{g} / \mathrm{mL}$ for the root extract.

The ABTS assay is a useful tool for the determination of the antioxidant activity of lipophilic and hydrophilic compounds. The ABTS radical cation reacts rapidly with antioxidant compounds because of its solubility in both aqueous and organic solvents [53]. The N. alba extracts possessed a high antioxidant capacity for ABTS inhibition, with $\mathrm{IC}_{50}$ values as low as $10 \mu \mathrm{g} / \mathrm{mL}$ for the root extract and $12 \mu \mathrm{g} / \mathrm{mL}$ for the leaf extract. The percentage of ABTS inhibition was $78.2 \%$ for the root extract and $77 \%$ for the leaf extract.

The FRAP assay relies on the ability of antioxidants to reduce iron (III) to iron (II), through the reaction with 2,4,6-tris(2-pyridyl)-s-triazine, forming a violet blue color [54]. The FRAP assay provides a direct estimation of the reductants in a sample and it is based on the ability of the analyte to reduce the $\mathrm{Fe}^{3+} / \mathrm{Fe}^{2+}$ couple. The N. alba extracts showed good ferric reducing antioxidant power, being the scavenging activity of the leaf and root extracts $74.6 \%$ and $79.7 \%$, respectively. The activity presented $\mathrm{IC}_{50}$ values as low as $30 \mu \mathrm{g} / \mathrm{mL}$ for the leaf extract and $13 \mu \mathrm{g} / \mathrm{mL}$ for the root extract.

The root extract exhibited a higher antioxidant activity (and a lower $\mathrm{IC}_{50}$ values) than the leaf extract. Consistently, Trolox equivalent values for the BCB, ABTS and FRAP assays were higher for the root extract than for the leaf extract. Trolox equivalent values for the root extract were as follows: 79,371 $\mu \mathrm{g}$ TEq/1 g (BCB assay), $1950 \mu \mathrm{g}$ TEq/1 g (ABTS assay) and $2407 \mu \mathrm{g}$ TEq/1 g (FRAP assay). Trolox equivalent values for the leaf extract were as follows: $28,933 \mu \mathrm{g}$ TEq/ $\mathrm{g}$ (BCB assay), $1309 \mu \mathrm{g}$ TEq/ $1 \mathrm{~g}$ (ABTS assay) and $2245 \mu \mathrm{g} \mathrm{TEq} / 1 \mathrm{~g}$ (FRAP assay). Our results are in accord with those of the literature 
data, which showed strong scavenging activity of DPPH radical for the aqueous and ethanolic flower and rhizome extracts of Nymphaea alba [55-57].

In summary, the $\mathrm{BCB}, \mathrm{ABTS}$ and FRAP measurements indicate the stability of the bioactive compounds from N. alba leaf and root extracts, which means that the antioxidant activities and $\mathrm{IC}_{50}$ values remain constant and act for a long period of time.

\subsection{Electrochemical Evaluation of Antioxidant Capacity}

Electrochemical investigations of both $N$. alba extracts $(1 \mathrm{mg} / \mathrm{mL}$ in methanol) were performed using cycling voltammetry and UV-Vis spectroscopy. Samples showed light positive potential from the open circuit potential measurements, with the leaf extract presenting a potential about $30 \mathrm{mV}$ more positive when compared to the root extract. The cyclic voltammograms of the root extract revealed moderate electrochemical activity compared with those obtained from the leaf extract. The N. alba extracts exhibited an intensity of anodic current (Ipa) up to $10.20 \mu \mathrm{A}$ for the leaf extract and up to $6.32 \mu \mathrm{A}$ for the root extract. The quercetin $\left(10^{-3} \mathrm{M}\right)$, as the major antioxidant compound, showed similar voltammogram profile as in the $N$. alba extracts (Figure $9 a$, blue line). The $\mathrm{E}_{1 / 2}$ of leaf and root extracts was $0.410 \mathrm{~V} \pm 10 \mathrm{mV}$ compared with the quercetin potential [58].

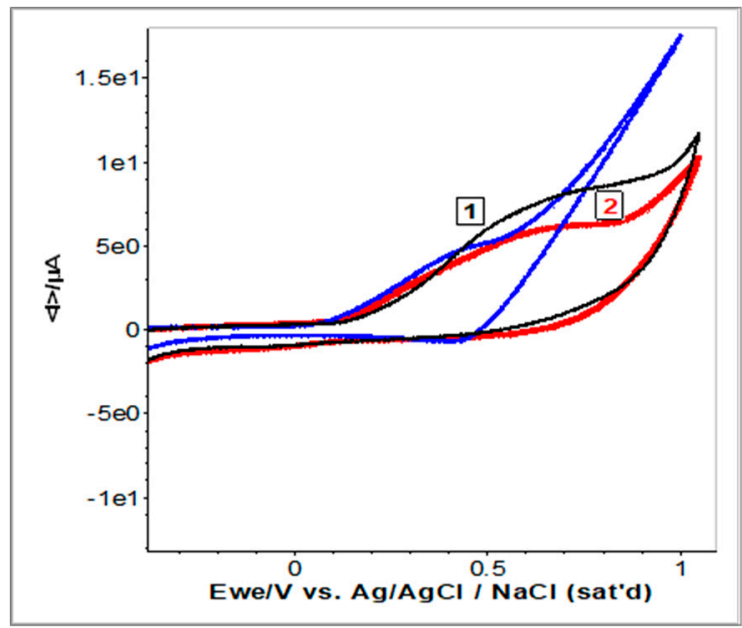

(a)

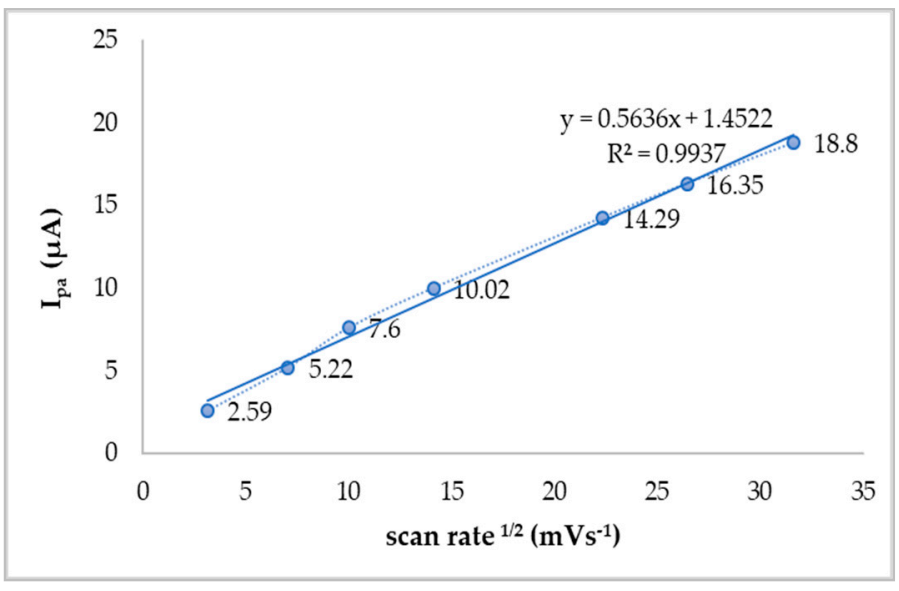

(b)

Figure 9. Cyclic voltammograms recorded for the N. alba leaf (1) and root (2) extracts compared with quercetin (blue line). $\mathrm{E}= \pm 1 \mathrm{~V}$ vs. $\mathrm{Ag} / \mathrm{AgClsat}$., scan rate of $100 \mathrm{mV} \mathrm{s}^{-1}$ (a). Dependence of the anodic current vs square root of the scan rates $(\mathbf{b})$. 
Five consecutive voltammograms were recorded at different sweep rates $\left(10-1000 \mathrm{mVs}^{-1}\right)$ and the current intensity increased with scan rate. No asymmetry was observed between currents $\left(\mathrm{I}_{\mathrm{pa}} / \mathrm{I}_{\mathrm{pc}}\right)$, an indicative of quasireversible process for the antioxidant compounds. The intensity of the anodic current varies linear with the scan rate due to the typical diffusion control processes (Figure 9b). Subsequently, UV-Vis spectra of both extracts were recorded before and after electrochemical measurements (Figure 10). Spectra profiles were almost similar for both N. alba extracts (Figure 10a). These results confirm the existence of antioxidant compounds in the extracts, as flavonoids range between $240-400 \mathrm{~nm}$. The $\lambda_{\max }$ of quercetin is at $385 \mathrm{~nm}$ [58], and its oxidative degradation exposed to electrochemical measurements is highlighted in Figure 10b.

Therefore, the observed electrochemical process supports the relevant antioxidant activity of $N$. alba extracts, which can be attributed to quercetin [22,58], one of the flavonoids present in the leaf extracts.

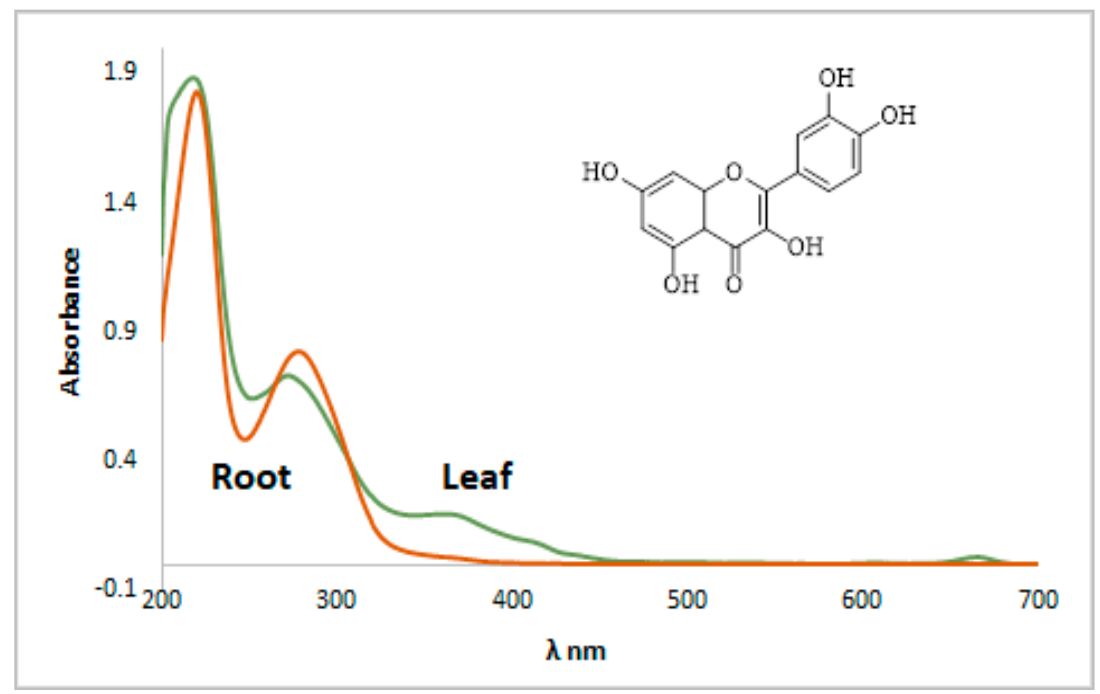

(a)

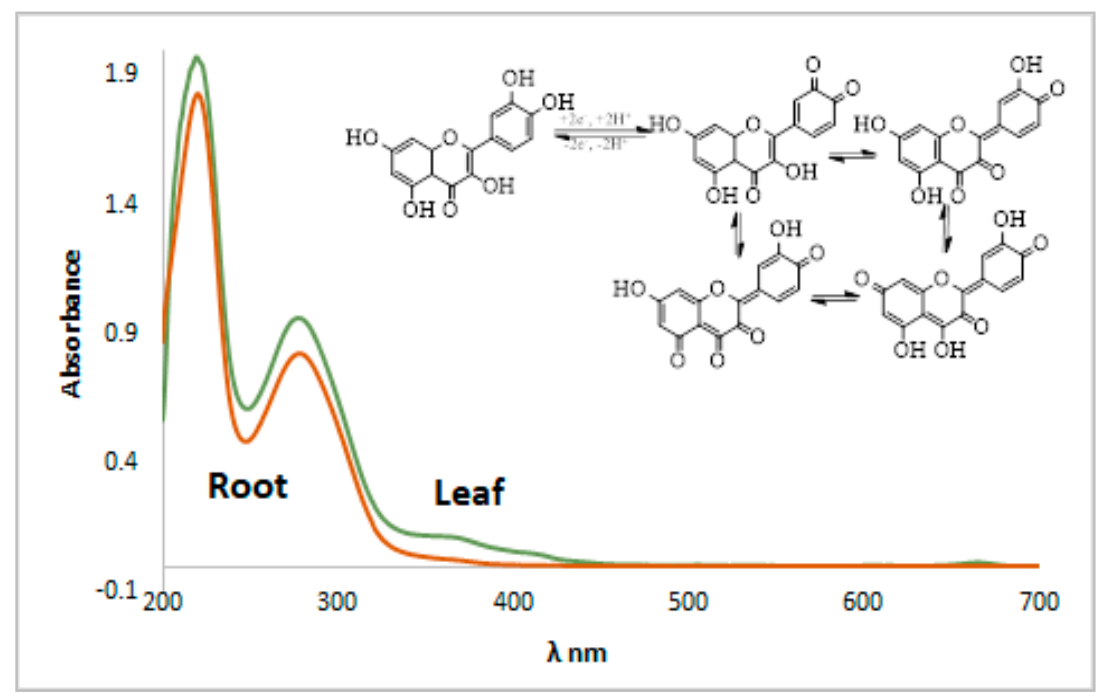

(b)

Figure 10. UV-VIS spectra recorded for the N. alba leaf and root methanolic extracts before (a) and after cyclic voltammetry experiments (b). 
The presence of quercetin was previously confirmed by HPLC-MS/MS analysis using quercetin as standard [22]. The identification was performed based on their characteristic $[\mathrm{M}-\mathrm{H}]^{-}$and MS/MS fragmentation profile, according to the literature data, the MS spectra providing a parent ion at $301 \mathrm{~m} / \mathrm{z}$, and a fragment ion at $150 \mathrm{~m} / \mathrm{z}$. Using reference standards, the chromatographic analysis (Figure 11) has led to the identification of different fragments of other polyphenolic compounds as phenolic acids, flavonoids, tannins, and other non-flavonoid polyphenols [22].

Overall, 27 bioactive compounds (caffeic acid, p-coumaric acid, chlorogenic acid, naringin, naringenin, vanillic acid, quercetin, rutin, HHDP-hexoside, corilagin, tannic acid, gallic acid, ferulic acid, ellagic acid, ellagic acid pentoside, quinic acid, castalin, orientin, apigenin, luteolin, brevifolin, cinnamic acid derivative) are reported for the methanolic extracts of N. alba from the Danube Delta landscape; of these, 26 were found in leaf extracts and 22 in root extracts [22].

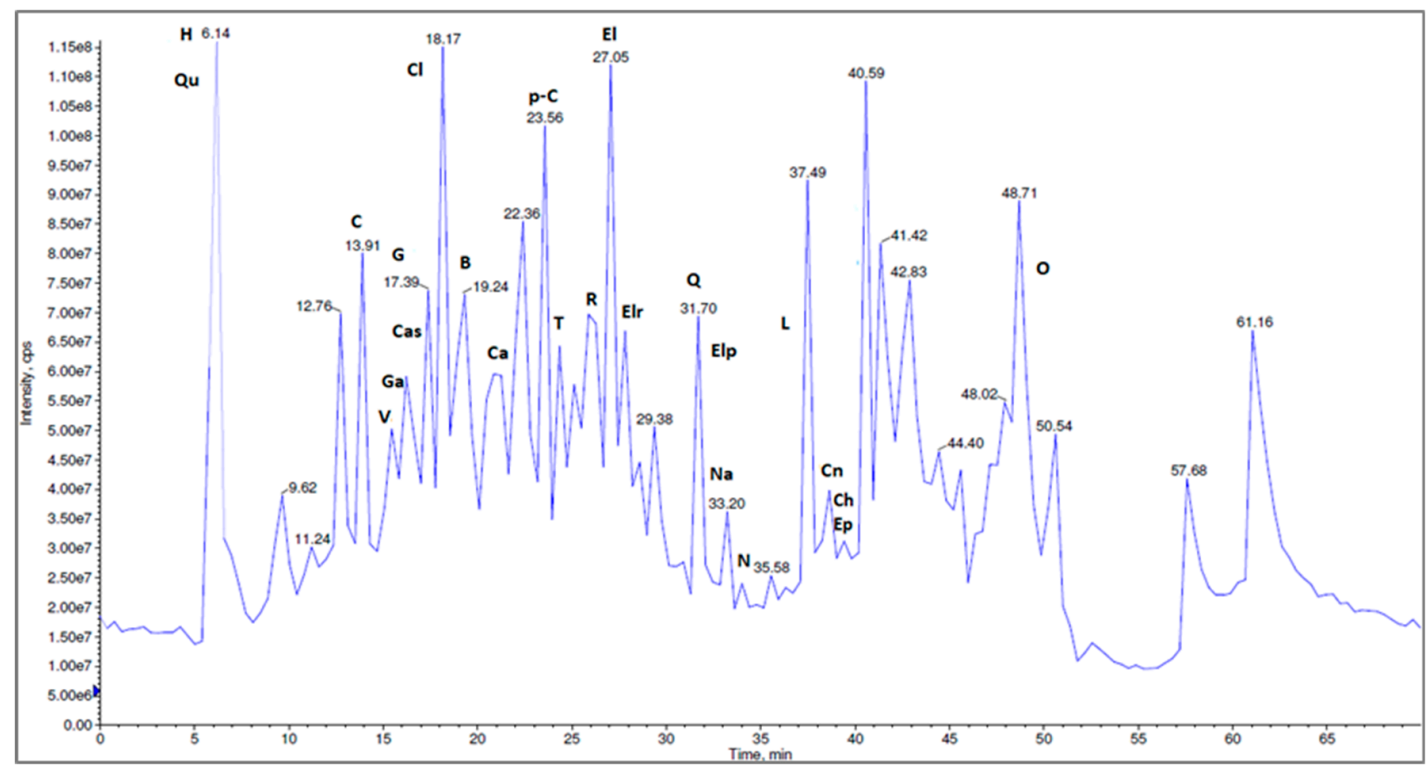

Figure 11. The LC-MS/MS chromatographic separation of the methanolic N. alba leaf extract (H-HHDP-hexoside, Qu-quinic acid, C-corilagin, V-vanillic acid, Cas-castalin, Ga-gallic acid, G-geraniin, Ca-caffeic acid, p-C-coumaric acid, T-tannic acid, R-rutin, El-ellagic acid, Elr-ellagic rhamnosyl acid, Elp-ellagic pentoside acid, Cn-cinnamic acid derivative, Na-naringenin, $\mathrm{N}$-naringin, $\mathrm{Ch}$-catechin, Ep-epicatechin, Cl-chlorogenic acid, Q-quercetin, L-luteolin, B-brevifolin, O-orientin).

Compared with the root extract, the leaf extract contains four additional compounds-chlorogenic acid, quercetin, luteolin and cinnamic acid derivative- but the root contains two compounds that are missing from the leaves: apigenin and ferulic acid. All of these bioactive compounds were found to exert a variety of pharmacological effects, including antitumoral, antimicrobial, and antioxidant (Table 5). The mechanism of action implicated in this type of compound is through inhibition of efflux pumps, inhibition of fungal growth, reduction in number of yeast cells and germ tubes, which ultimately results in induction of cell death or apoptosis [39]. Therefore, these structural differences between phytochemicals of two extracts could explain the differences between the biological activities. 
Table 5. Identified compounds from N. alba leaf and root extracts and their biological properties.

\begin{tabular}{|c|c|c|c|}
\hline No. & $\begin{array}{l}\text { Identified Compounds } \\
\text { from } N \text {. alba Extracts }\end{array}$ & Biologic Properties & References \\
\hline 1 & HHDP-hexoside & $\begin{array}{l}\text { antioxidant, anti-inflammatory, antitumor, and apoptotic } \\
\text { properties; antibacterial activity against E. coli, S. aureus, } \\
\text { A. baumannii, P. aeruginosa; }\end{array}$ & [59-62] \\
\hline 2 & Quinic acid & $\begin{array}{l}\text { induces cancer cell death by modulating the expression } \\
\text { of Akt, phospho-Akt, and cell cycle pathway; } \\
\text { anti-prostate cancer, attenuates Alzheimer's disease }\end{array}$ & [63-65] \\
\hline 3 & Vanillic acid & $\begin{array}{l}\text { antibacterial, antioxidant and antihypertensive activities, } \\
\alpha \text {-glucosidase and tyrosinase inhibitory, effects against } \\
\text { dextran sulfate sodium (DSS)-induced ulcerative colitis }\end{array}$ & [66-69] \\
\hline 4 & Gallic acid & $\begin{array}{l}\text { antiviral and antioxidant activities, anticancer activity by } \\
\text { inducing apoptosis, downregulating genes involved in } \\
\text { cell cycle and angiogenesis, and stimulating a cellular } \\
\text { immune response }\end{array}$ & {$[24,70-73]$} \\
\hline 5 & Castalin & antimicrobial, anti-inflammatory & [74] \\
\hline 6 & Chlorogenic acid & $\begin{array}{l}\text { inhibiting gene } \beta \text {-catenin and inducting genes GSK- } 3 \beta \text {, } \\
\text { antispasmodic and antioxidant activities, inhibition of } \\
\text { the HIV-1 integrase and inhibition of the mutagenicity of } \\
\text { carcinogenic compounds }\end{array}$ & {$[75,76]$} \\
\hline 7 & Corilagin & $\begin{array}{l}\text { anticancer, anti-hyperalgesic, antioxidant, } \\
\text { anti-inflammatory, hepatoprotective, and antitumor } \\
\text { actions, induced apoptosis and autophagic cell death }\end{array}$ & $\begin{array}{l}{[24,73,77,} \\
78]\end{array}$ \\
\hline 8 & Brevifolin & antioxidant, anti-inflammatory and anticancer & {$[61]$} \\
\hline 9 & Caffeic acid & $\begin{array}{l}\text { inhibiting gene } \beta \text {-catenin and inducting genes GSK-3 } \beta \text {, } \\
\text { antispasmodic and antioxidant activities }\end{array}$ & {$[75,76]$} \\
\hline 10 & p-Coumaric acid & $\begin{array}{l}\text { anti-inflammatory, anti-tyrosinase and antimicrobial } \\
\text { activities, antispasmodic and antioxidant activities }\end{array}$ & {$[61,76,79]$} \\
\hline 11 & Tannic acid & $\begin{array}{l}\text { anticancer activity by inducing apoptosis, } \\
\text { downregulating genes involved in cell cycle and } \\
\text { angiogenesis, and stimulating a cellular immune } \\
\text { response, Antioxidant and } \alpha \text {-amylase } \\
\text { inhibitory activities }\end{array}$ & {$[24,80,81]$} \\
\hline 12 & Rutin & $\begin{array}{l}\text { antioxidant activity, apoptosis, down regulating genes } \\
\text { involved in cell cycle and angiogenesis antimetastatic, } \\
\text { induces glutathione and glutathione peroxidase activities }\end{array}$ & {$[23,82,83]$} \\
\hline 13 & Ellagic acid & $\begin{array}{l}\text { anticancer activity by inducing apoptosis, } \\
\text { downregulating genes involved in cell cycle and } \\
\text { angiogenesis, and stimulating a cellular immune } \\
\text { response; antioxidant and antiviral activities, inhibit } \\
\alpha \text {-glucosidase and } \alpha \text {-amylase }\end{array}$ & $\begin{array}{l}{[24,72,84,} \\
85]\end{array}$ \\
\hline 14 & Ellagic acid rhamnosyl & $\begin{array}{l}\text { anticancer activity by inducing apoptosis, } \\
\text { downregulating genes involved in cell cycle and } \\
\text { angiogenesis, and stimulating a cellular } \\
\text { immune response }\end{array}$ & {$[24,73]$} \\
\hline 15 & Quercetin & $\begin{array}{l}\text { apoptosis, down regulating genes involved in cell cycle } \\
\text { and angiogenesis inhibited melanoma cell inhibits } \\
\text { development of Candida spp.; antifungal }\end{array}$ & {$[23,39,59]$} \\
\hline 16 & Ellagic acid-pentoside & $\begin{array}{l}\text { anticancer activity by inducing apoptosis, } \\
\text { downregulating genes involved in cell cycle and } \\
\text { angiogenesis, and stimulating a cellular immune } \\
\text { response, antioxidant activity }\end{array}$ & {$[24,73,84]$} \\
\hline
\end{tabular}


Table 5. Cont.

\begin{tabular}{|c|c|c|c|}
\hline No. & $\begin{array}{l}\text { Identified Compounds } \\
\text { from N. alba Extracts }\end{array}$ & Biologic Properties & References \\
\hline 17 & Naringenin & $\begin{array}{l}\text { anticancer effect arrests cell development at the G0/G1 } \\
\text { phase; inhibits Candida spp. growth }\end{array}$ & {$[39,43,60]$} \\
\hline 18 & Naringin & $\begin{array}{l}\text { anticancer effect arrests cell development at the G0/G1 } \\
\text { phase; inhibits Candida spp. growth }\end{array}$ & {$[39,43,60]$} \\
\hline 20 & Luteolin & $\begin{array}{l}\text { anticancer associated with the induction of apoptosis, } \\
\text { and inhibition of cell proliferation, metastasis and } \\
\text { angiogenesis }\end{array}$ & {$[60,86]$} \\
\hline 21 & Ferulic acid & $\begin{array}{l}\text { synergistic effects against Candida albicans; } \\
\text { anti-inflammatory and antioxidant activities, } \\
\text { antispasmodic and antioxidant activities }\end{array}$ & {$[76,87]$} \\
\hline 22 & Cinnamic acid derivative & $\begin{array}{l}\text { anti-inflammatory, anti-tyrosinase and antimicrobial } \\
\text { activities }\end{array}$ & [79] \\
\hline 23 & Catechin & anticancer activity & {$[60,88]$} \\
\hline 24 & Epicatechin & anticancer activity & {$[60,88]$} \\
\hline 25 & Apigenin & $\begin{array}{l}\text { anticancer effect by arresting cell development at the } \\
\text { G0/G1 phase; the inhibition of phosphorylation of } \\
\text { mitogen-activated protein kinase (MAPK) }\end{array}$ & {$[60]$} \\
\hline 26 & Orientin & $\begin{array}{l}\text { antioxidant, antiviral and antibacterial activities, } \\
\text { anti-inflammatory neuroprotective or } \\
\text { antidepressant-like effects }\end{array}$ & [89] \\
\hline
\end{tabular}

\section{Materials and Methods}

\subsection{General}

All the reagents and organic solvents used for analysis were purchased from Sigma Aldrich (Steinheim, Germany). Absorbance and fluorescence measurements for antioxidant activities were done using a multiwell plate reader (Tecan Pro 200, Tecan Trading AG, Männedorf, Switzerland). The N. alba plant was collected in June 2017, from the Somava-Parches Lagoon Complex, situated in the Danube Delta Biosphere Reserve of Romania. Specimens were deposited at the Botanical Garden of Galati, Romania [22].

\subsection{Preparation of N. alba Extracts}

Leaf and root of the N. alba species were dried at room temperature until completely drying and then finely ground. $10 \mathrm{~g}$ of ground powder plant was extracted with $100 \mathrm{~mL}$ of methanol for $2 \mathrm{~h}$, by a mass/volume ratio of $1 / 10(\mathrm{w} / \mathrm{v})$ using an ultrasonic bath. The extracts were filtered initially through cotton and then through quantitative filter paper and then concentrated under reduced pressure in a rotary evaporator to remove the solvent. The obtained crude extracts were stored refrigerated at $4{ }^{\circ} \mathrm{C}$ until further use.

\subsection{Toxicity Evaluation of N. alba Extracts on Wheat Seed Germination}

Prior to germination the wheat seeds were surface-sterilized for about 5 min with 1\% sodium hypochlorite solution to prevent fungal growth, followed by washing for five times with ultrapure water. Twenty-five uniform and disinfected wheat seeds were selected and incubated in germination boxes with double layers of paper filter in the presence and in the absence of different concentrations $(10,100,500$ and $1000 \mu \mathrm{g} / \mathrm{mL})$ of $N$. alba leaf and root extracts. Four replicates of 25 seeds were used for each sample and control. Control seeds were treated with distilled water only. The germination boxes were kept in darkness at room temperature $\left(24^{\circ} \mathrm{C}\right)$ for 5 days. In the germination process, the wheat 
seeds with a root longer than $1 \mathrm{~mm}$ were considered to be germinated. After 5 days, the shoot and root length of wheat seeds were measured (in $\mathrm{mm}$ ). The germination index (GI) was obtained by dividing the germination percentage $(\mathrm{G} \%$ ) by the relative root growth (RRG \%). The vigor index (VI) was also obtained. Parameters were calculated as follows [90]:

$$
\begin{gathered}
\mathrm{GI}=\frac{\mathrm{G} \%}{\mathrm{RRG} \%} \\
\mathrm{G} \%=\frac{\text { No. of germinated wheat seeds in sample }}{\text { No. of germinated wheat seeds in control }} * 100 \\
\mathrm{RRG} \%=\frac{\text { Mean root length in sample }}{\text { Mean root length in control }} * 100 \\
\mathrm{VI}=\mathrm{G} \% * \frac{\text { Mean of root length }}{\text { Mean of shoot length }}
\end{gathered}
$$

Tolerance index (TI) combines several individual measurement parameters and generates an index between 0 and 1 . A low TI indicates a high susceptibility to biotic or abiotic stresses originating from the N. alba leaf and root extracts. The TI a and TI b were calculated using [91]:

$$
\begin{gathered}
\mathrm{TI} \mathrm{a}=\frac{\text { Germination rate of treated sample }(\%)}{\text { Germination rate of control }(\%)} * \frac{\text { Root length }(\mathrm{mm}) \text { of treated sample }}{\text { Root length }(\mathrm{mm}) \text { of control }} \\
\mathrm{TI} \mathrm{b}=\frac{\text { Germination rate of treated sample }(\%)}{\text { Germination rate of control }(\%)} * \frac{\text { Dry matter }(\mathrm{g}) \text { of treated sample }}{\text { Dry matter }(\mathrm{g}) \text { of control }}
\end{gathered}
$$

Confocal Laser Scanning Microscopy (CLSM)

The germination of the wheat seeds was followed by confocal laser scanning microscopy using a Zeiss system (LSM 710) equipped with a diode laser (405 nm), Ar-laser (458, 488, $514 \mathrm{~nm})$, DPSS laser (diode pumped solid state e $561 \mathrm{~nm}$ ) and HeNe-laser $(633 \mathrm{~nm})$. To estimate the possible toxic effects of the extracts on the wheat germs, wheat seeds were germinated in the presence of different concentrations of the N. alba leaf and root extracts. The microscopic glass slides with sections through root and shoot of samples were observed using a Zeiss AxioObserver Z1 inverted microscope equipped with a 40× apochromatic objective (numerical aperture 1.4) and the FS49, FS38 and FS15 filters. The parameters used for image acquisition were line scan mode, mean method, average number 4, speed 6, 12-bit depth. The images were analyzed with the ZEN 2012 SP1 software (Black Edition).

\subsection{Assessment of Antifungal Activity of N. alba Extracts}

\subsubsection{Determination of N. alba Extracts' Minimum Inhibitory Concentration (MIC)}

The antifungal activity of the N. alba extracts against Candida glabrata CBS 138, Candida albicans SC 5134, Candida parapsilosis ATCC22019, and Candida tropicalis ATCC750 was assessed based on the determination of MIC values, defined as the lowest concentration that inhibited fungal growth. The fluconazole (FLC) was used as control. MIC values were experimentally determined in a 96 well plate using RPMI 1640 medium (Sigma) containing $20 \mathrm{~g} / \mathrm{L}$ glucose (final concentration), and buffered to pH 7.0 with $0.165 \mathrm{M}$ morpholine propane sulphonic acid (MOPS; SIGMA) using the broth microdilution method recommended by EUCAST (European Committee on Antimicrobial Susceptibility Testing) for Candida spp. [92], and as previously described [9,93]. The extracts were sequentially 1:2 diluted in order to obtain final concentrations ranging between 0.23 and $2000 \mu \mathrm{g} / \mathrm{mL}$. The concentration of the FLC ranged between 0.23 and $250 \mu \mathrm{g} / \mathrm{mL}$ After inoculation, the 96-well round-bottom polystyrene microtiter plates (Greiner Bio-One) were incubated at $35{ }^{\circ} \mathrm{C}$ for $24 \mathrm{~h}$ and the optical density was 
determined at $530 \mathrm{~nm}$ using a SpectrostarNano microplate reader (BMG Labtech, Freiburg, Germany). The experiments were done in triplicate, and MICs were calculated as the mean values.

\subsubsection{Assessment of Fungicidal/Fungistatic Activity}

To assess the fungistatic or fungicidal activity of the extracts against C. glabrata CBS 138, the CFUs were counted for the wells containing the concentrations of extracts above and below the estimated MIC. For this purpose, $100 \mu \mathrm{L}$ of each cell suspension of C. glabrata CBS 138 treated with N. alba leaf and root extracts were serial diluted (1:10) in $\mathrm{NaCl} 0.9 \%$ and were plated in Yeast Extract-Peptone-Dextrose (YPD) Agar plates. The plates were incubated for $24 \mathrm{~h}$ at $30{ }^{\circ} \mathrm{C}$ and the total number of CFUs was determined. The results are presented as Log10 CFU per $\mathrm{mL}$ (Log10 CFUs/mL).

\subsection{In Vitro Cytotoxicity Assessment of N. alba Extracts on Normal and Tumor Cell Lines}

The effect of N. alba extracts on the cellular viability of A2780/A2780cisR ovarian (sensitive and resistant to cisplatin) (Sigma-Aldrich, Darmstadt, Germany), MCF7 breast (hormone dependent) (ATCC), LNCaP prostate (hormone dependent) (ATCC) cancer cells, and V79 normal lung fibroblasts (ATCC), were measured using the MTT assay (MTT $=3-(4,5$-dimethylthiazol-2-yl) -2,5-diphenyltetrazolium bromide reagent) based on the conversion of the tetrazolium salt to formazan by metabolic active cells. Cells were grown in DMEM + Glutamax I (V79 and MCF7) or RPMI 1640 (LNCaP, A2780/A2780cisR) media, supplemented with 10\% fetal bovine serum (FBS) and 1\% penicillin/streptomycin. For the assays, cells were seeded in 96-well plates and left $24 \mathrm{~h}$ to adhere in a $5 \% \mathrm{CO} 2$ incubator at $37^{\circ} \mathrm{C}$. $200 \mu \mathrm{L}$ of cell culture media with the extracts at serial dilutions were applied to each well. After $24 \mathrm{~h}$ of incubation, the supernatant was removed, MTT ( $0.5 \mathrm{mg} / \mathrm{mL}$ PBS) was added, and the plates were incubated for $3 \mathrm{~h}$ at $37^{\circ} \mathrm{C}$. The purple formazan formed was dissolved in $200 \mu \mathrm{L}$ DMSO. Optical density was measured at $570 \mathrm{~nm}$ using a microplate reader (Power Wave Xs, Bio-Tek, Winooski, USA).

\section{Analysis of Combined N. alba Extracts and Cisplatin Cytotoxic Effects}

For the analysis of the combined effects of N. alba extracts and cisplatin, the concentration ratio of the two drugs was set from the MTT assays on the A2780 and A2780cisR cancer cell lines. Five doses of N. alba extract and cisplatin were used from serial dilutions. The combined method was used for the evaluation of the potential synergism between N. alba extract and cisplatin [58]. The combination index (CI) was calculated by the CompuSyn software and CI $<1, \mathrm{CI}=1$, and CI $>1$, indicated synergy, additive effect, and antagonism, respectively $[46,94,95]$.

\subsection{Antioxidant Capacity Assays}

\subsection{1. $\beta$-Carotene Bleaching}

$\beta$-Carotene bleaching was assessed by the measurement of the inhibition of formation of volatile organic compounds and the diene conjugated hydro-peroxides, resulting from the oxidation of linoleic acid. A solution of $2 \mathrm{mg}$ of $\beta$-carotene in $1 \mathrm{~mL}$ of chloroform was introduced into a round bottom flask containing $2 \mathrm{mg}$ of linoleic acid and $200 \mathrm{mg}$ of Tween 40. After the chloroform evaporation, $100 \mathrm{~mL}$ of distilled water saturated with oxygen were added with vigorous stirring. $100 \mu \mathrm{L}$ from this new solution was added in a 96-well plate containing concentrations between 1-500 $\mu \mathrm{g} / \mathrm{mL}$ of extract samples. Distilled water was used as the negative control. Absorbance was measured at $460 \mathrm{~nm}$ at different intervals of time (30 min, $60 \mathrm{~min}, 120 \mathrm{~min}$ and $180 \mathrm{~min}$ ). A linear standard curve of Trolox was made, using amounts of Trolox between 0 and $250 \mu \mathrm{g}$. Results are expressed as $\mu \mathrm{g}$ TEq/g sample [47,96].

\subsubsection{ABTS Assay}

The ABTS radical cation stock solution was prepared by mixing $7.8 \mathrm{mM} 2,20$-azinobis (3-ethylbenothiazoline-6-sulfonic acid) diammonium salt solution and $140 \mathrm{mM}$ potassium persulfate 
solution in equal quantities. The mixture was allowed to react for $12 \mathrm{~h}$ at room temperature in dark conditions. The solution was then diluted to obtain an absorbance between $1.1 \pm 0.02$ units at $734 \mathrm{~nm}$. Fresh ABTS radical cation solution were prepared for each assay. Extracts in concentrations in the range $1-500 \mu \mathrm{g} / \mathrm{mL}$ were mixed with the ABTS radical cation solution in a 96-well plate. The absorbance was then measured at $734 \mathrm{~nm}$ after 30,60, and 90 min of incubation. A linear standard curve of Trolox was made using amounts of Trolox between 0 and $250 \mu \mathrm{g}$. Results are expressed as $\mu \mathrm{g}$ of Trolox equivalents (TEq) per g of sample (TEq/g) [97].

\subsubsection{FRAP}

A Ferric Reducing Antioxidant Power (FRAP) assay was carried out according to Jones et al. [54] with some modifications. Briefly, the FRAP working solution was prepared by mixing $100 \mathrm{~mL}$ acetate buffer (250 mM, pH 3.6), $10 \mathrm{~mL}$ 2,4,6-tris(2-pyridyl)-s-triazine (TPTZ) solution (10 mM in $40 \mathrm{mM} \mathrm{HCl}$ ) and $10 \mathrm{~mL} \mathrm{FeCl} 3(20 \mathrm{mM}) .50 \mu \mathrm{L}$ extracts, in different concentrations $(1-500 \mu \mathrm{g} / \mathrm{mL})$, were mixed with $200 \mu \mathrm{L}$ of FRAP solution in a 96-well plate and incubated for $10 \mathrm{~min}$ at $37^{\circ} \mathrm{C}$. Then the absorbance was measured after 10, 20,30, and $40 \mathrm{~min}$ at $593 \mathrm{~nm}$. The linear standard curve of Trolox was prepared using Trolox amounts ranging from 0 to $250 \mu \mathrm{g}$. Results are expressed as $\mu \mathrm{g}$ TEq/g sample.

\subsubsection{Electrochemical Characterization of N. alba Extracts}

The electrochemical investigations using cyclic voltammetry (CV) were employed for the characterization of N. alba leaf and root extracts. The electrochemical system consisted of an electrochemical cell $(20 \mathrm{~mL})$ with three electrodes: glass carbon electrode as working electrode, Ag/AgClsat $(\mathrm{E}=0.194$ $\mathrm{V} / \mathrm{NHE}$ ) as reference electrode and $\mathrm{Pt}$ wire as counter electrode. The measurements at room temperature were conducted with Bio-logic potentiostat/galvanostat SP-150 (Claix, France). The applied potential was $\mathrm{E}= \pm 1 \mathrm{~V}$ vs. Ag/AgClsat, with different sweep rate potential between 10 to $1000 \mathrm{mV} \mathrm{s}^{-1}$. The working electrode was polished with BASi ${ }^{\circledR}$ polishing kit (alumina and diamond slurries) followed by washing with methanol after each voltammetry experiment. The quercetin was also analyzed as a main component of the extracts. Fresh solutions of $N$. alba leaf and root extracts at $1 \mathrm{mg} / \mathrm{mL}$ and quercetin $\left(10^{-3} \mathrm{M}\right)$, were prepared in methanol. UV-Vis spectra were recorded before and after cyclic voltammetry experiment using SPECORD 210 PLUS double-beam spectrophotometer (Analytik Jena, Jena, Germany). Spectra were performed in the wavelength range of 200 to $700 \mathrm{~nm}$ using quartz cuvettes of $1 \mathrm{~cm}$.

\subsection{Statistical Analysis}

All the experiments were performed in triplicate, independently, and the data presented were expressed as the mean \pm standard deviation. Data were analyzed for statistical significance using the Microsoft Excel program, CompuSyn Software and GraphPad Prism Software.

\section{Conclusions}

Considering the imperative necessity of discovering new therapeutic agents, in this study, we evaluated for the $N$. alba aquatic plant the antifungal, antitumoral and antioxidant activities of methanolic leaf and root extracts.

The use of simple tests of seed germination allowed us to assess the toxic effects of N. alba extracts, and the toxicity studies exhibited no inhibitory effect on wheat seed germination. The confirmation of the non-toxic nature of the extracts was obtained from confocal laser scanning microscopy images.

The antioxidant activity evaluated by $\beta$-carotene bleaching, ABTS and FRAP assays was proven to be high, and the presence of the antioxidant flavonoid, quercetin, was confirmed by cyclic voltammetry.

The antifungal activity experiments showed that both extracts have high antifungal activity against the C. glabrata CBS 138 strain, acting as a fungistatic agent.

The N. alba leaf and root extracts showed a promising cytotoxic effect against ovarian A2780 and breast MCF7 cells and were less cytotoxic against noncancerous V79 cells indicating a more selective 
profile for cancer cells. In the cisplatin-resistant ovarian cells, N. alba leaf extract combined with cisplatin, inhibited the growth of the cells, suggesting a strong synergism in the growth inhibitory effect.

The results of the antifungal and antitumor activity of N. alba extracts, as well as studies on their impact on seed germination, suggest that the $N$. alba may act as an immune booster and prevent infection in immunosuppressed cancer patients. Further work is necessary to validate the benefits of N. alba extracts as human health promoters.

Altogether, the results presented here encourage us to continue our research into the exploitation of the bioactive potential of the N. alba species for the treatment of cancer and infection diseases.

Author Contributions: Conceptualization, M.C., F.M., and R.M.D.; Methodology, M.C., B.F., G.C., V.B., A.V.I., F.M., S.A.S., J.H.L., F.M., R.M.D.; Software, M.C.; Validation, M.C.; Formal analysis, A.V.I.; Investigation, M.C., B.F., V.B., F.M., J.H.L., S.A.S., R.M.D.; Resources, B.F., G.C., J.H.L., F.M., R.M.D.; Data curation, M.C., B.F., G.C., V.B., S.A.S., F.M. and R.M.D.; Writing—original draft preparation, M.C., V.B., S.A.S.; Writing—review and editing M.C., B.F., G.C., F.M., J.H.L., S.A.S., R.M.D.; Visualization, B.F.; Supervision, B.F., G.C., F.M., R.M.D.; Project administration, R.M.D.; Funding acquisition, F.M., R.M.D. All co-authors contributed to the revision of the final version of the manuscript. All authors have read and agreed to the published version of the manuscript.

Funding: M.C. acknowledges the support of this work by the project ANTREPRENORDOC, in the framework of Human Resources Development Operational Programme 2014-2020, financed from the European Social Fund under the contract number 36355/23.05.2019 HRD OP /380/6/13-SMIS Code: 123847. The authors from Instituto Superior Técnico, Portugal, thank the Fundação para a Ciência e Tecnologia (FCT) for the financial support through UID/MULTI/04349/2013 and UID/BIO/04565/2019.

Acknowledgments: S.A.S. acknowledges a research contract from IST-ID.

Conflicts of Interest: The authors declare no conflict of interest. The funders had no role in the design of the study; in the collection, analyses, or interpretation of data; in the writing of the manuscript, or in the decision to publish the results.

\section{References}

1. Jamil, M.M.A.; Ganeson, S.; Mammam, H.B.; Wahab, R.A. Artocarpus altilis extract effect on cervical cancer cells. Mater. Today Proc. 2018, 5, 15559-15566. [CrossRef]

2. Krishnan, G.S.; Sebastian, D.; Savarimuthu, I.; Poovathumkal, J.A.; Fleming, A.T. In vitro and in silico anticancer effect of combined crude acetone extracts of Plumbago zeylanica L., Limonia acidissima L. and Artocarpus heterophyllus Lam. Synergy 2017, 5, 15-23. [CrossRef]

3. Ashraf, A.; Sarfraz, R.A.; Mahmood, A.; Ud Din, M. Chemical composition and in vitro antioxidant and antitumor activities of Eucalyptus camaldulensis Dehn. Leaves. Ind. Crops Prod. 2015, 74, 241-248. [CrossRef]

4. Hossain, M.A.; Nagooru, M.R. Biochemical Profiling and Total Flavonoids Contents of Leaves Crude Extract of Endemic Medicinal Plant Corydyline terminalis L. Kunth. Pharmacogn. J. 2011, 3, 25-30. [CrossRef]

5. Alasmary, F.A.S.; Awaad, A.S.; Kamal, M.; Alqasoumi, S.I.; Zain, M.E. Antitumor activity of extract and isolated compounds from Drechslera rostrata and Eurotium tonophilum. Saudi Pharm. J. 2018, 26, 279-285. [CrossRef] [PubMed]

6. Galocha, M.; Pais, P.; Cavalheiro, M.; Pereira, D.; Viana, R.; Teixeira, M.C. Divergent Approaches to Virulence in C. albicans and C. glabrata: Two Sides of the Same Coin. Int. J. Mol. Sci. 2019, 20, 2345. [CrossRef] [PubMed]

7. Nami, S.; Aghebati-Maleki, A.; Morovati, H.; Aghebati-Maleki, L. Current antifungal drugs and immunotherapeutic approaches as promising strategies to treatment of fungal diseases. Biomed. Pharm. 2019, 110, 857-868. [CrossRef]

8. Perlin, D.S.; Rautemaa-Richardson, R.; Alastruey-Izquierdo, A. The global problem of antifungal resistance: Prevalence, mechanisms, and management. Lancet Infect. Dis. 2017, 17, 383-392. [CrossRef]

9. Costa, J.P.; Pinheiro, M.J.F.; Sousa, S.A.; Botelho do Rego, A.M.; Marques, F.; Oliveira, M.C.; Leitão, J.H.; P Mira, N.; Carvalho, N.N.; Fernanda, M. Antimicrobial Activity of Silver Camphorimine Complexes against Candida Strains. Antibiotics 2019, 8, 144. [CrossRef]

10. Shoeb, M. Anticancer agents from medicinal plants. Bangladesh J. Pharmacol. 2006, 1, 35-41. [CrossRef]

11. Rana, S.; Dixit, S.; Mittal, A. Anticancer Effects of Chemotherapy and Nature Products. J. Med. Discov. 2017, 2, 2. [CrossRef] 
12. Ruijun, W.; Shi, W.; Yijun, X.; Mengwuliji, T.; Lijuan, Z.; Yumin, W. Antitumor effects and immune regulation activities of a purified polysaccharide extracted from Juglan regia. Int. J. Biol. Macromol. 2015, 72, 771-775. [CrossRef] [PubMed]

13. Benarba, B.; Pandiella, A. Colorectal cancer and medicinal plants: Principle findings from recent studies. Biomed. Pharmacother. 2018, 107, 408-423. [CrossRef] [PubMed]

14. Lakshmi, M.N.; Ramakrishanan, G.K.; Konda, V.G.R.; Roy, A.; Geetha, R.V. In vitro Antioxidant and Free Radical Scavenging Activity of Aqueous and Ethanolic Flower Extract of Nymphaea Alba. Int. J. Drug Dev. Res. 2011, 3, 252-258.

15. Seca, A.M.L.; Pinto, D.C.G.A. Plant Secondary Metabolites as Anticancer Agents: Successes in Clinical Trials and Therapeutic Application. Int. J. Mol. Sci. 2018, 19, 263. [CrossRef] [PubMed]

16. Varghese, E.; Samuel, S.M.; Abotaleb, M.; Cheema, S.; Mamtani, R.; Büsselberg, D. The "Yin and Yang" of Natural Compounds in Anticancer Therapy of Triple-Negative Breast Cancers. Cancers 2018, 10, 346. [CrossRef]

17. Nussbaumer, S.; Bonnabry, P.; Veuthey, J.L.; Fleury-Souverain, S. Analysis of anticancer drugs: A review. Talanta 2011, 85, 2265-2289. [CrossRef]

18. Dasari, S.; Tchounwou, P.B. Cisplatin in cancer therapy: Molecular mechanisms of action. Eur. J. Pharmacol. 2014, 740, 364-378. [CrossRef]

19. Demain, A.L.; Vaishnav, P. Natural products for cancer chemotherapy. Microb. Biotechnol. 2011, 4, 687-699. [CrossRef]

20. Deyou, T.; Woo, J.-H.; Choi, J.-H.; Janga, Y.P. A new natural product from the leaves of Olinia usambarensis and evaluation of its constituents for cytotoxicity against human ovarian cancer cells. S. Afr. J. Bot. 2017, 113, 182-185. [CrossRef]

21. Sisodiya, P.S. Plant Derived Anticancer Agents: A Review. Int. J. Res. Dev. Pharm. Life Sci. 2013, 2, $293-308$.

22. Cudalbeanu, M.; Ghinea, I.O.; Furdui, B.; Dah-Nouvlessounon, D.; Raclea, R.; Costache, T.; Cucolea, I.E.; Urlan, F.; Dinica, R.M. Exploring New Antioxidant and Mineral Compounds from Nymphaea alba Wild-Grown in Danube Delta Biosphere. Molecules 2018, 23, 1247. [CrossRef] [PubMed]

23. Iqbala, J.; Abbasi, B.A.; Batool, R.; Mahmood, T.; Ali, B.; Khalil, A.T.; Kanwal, S.; Shah, S.A.; Ahmad, R. Potential phytocompounds for developing breast cancer therapeutics: Nature's healing touch. Eur. J. Pharmacol. 2018, 827, 125-148. [CrossRef] [PubMed]

24. Gupta, A.; Singh, A.K.; Kumar, R.; Gangul, R.; Rana, H.K.; Pandey, K.P.; Sethi, G.; Bishayee, A.; Pandey, A.K. Corilagin in Cancer: A Critical Evaluation of Anticancer Activities and Molecular Mechanisms. Molecules 2019, 24, 3399. [CrossRef] [PubMed]

25. Nazir, S.; Qureshi, M.A.; Chat, O.A. Anti-tumor, Anti-oxidant and Anti-microbial potential of Nymphaea alba and Nymphaea mexicana flowers-A comparative study. Adv. Biomed. Pharm. 2015, 2, 196-204. [CrossRef]

26. Dash, B.K.; Sen, M.K.; Alam, K.; Hossain, K.; Islam, R.; Banu, N.A.; Rahman, S.; Jamal, A.H.M. Antibacterial activity of Nymphaea nouchali (Burm. f) flower. Ann. Clin. Microbiol. Antimicrob. 2013, 12. [CrossRef] [PubMed]

27. Supaphon, P.; Keawpiboon, C.; Preedanon, S.; Phongpaichit, S.; Rukachaisirikul, V. Isolation and antimicrobial activities of fungi derived from Nymphaea lotus and Nymphaea stellata. Mycoscience 2018, 59, 415-423. [CrossRef]

28. Chana, C.L.; Gana, R.Y.; Shah, N.P.; Corke, H. Polyphenols from selected dietary spices and medicinal herbs differentially affect common food-borne pathogenic bacteria and lactic acid bacteria. Food Control 2018, 92, 437-443. [CrossRef]

29. Martins, N.; Ferreira, I.C.F.R.; Henriques, M.; Silva, S. In vitro anti-Candida activity of Glycyrrhiza glabra L. Ind. Crops Prod. 2016, 83, 81-85. [CrossRef]

30. Iwashita, K.; Kobori, M.; Yamaki, K.; Tsushida, T. Flavonoids inhibit cell growth and induce apoptosis in B16 melanoma 4A5 cells. Biosci. Biotechnol. Biochem. 2000, 64, 1813-1820. [CrossRef]

31. Khan, N.; Sultana, S. Anticarcinogenic effect of Nymphaea alba against oxidative damage, hyperproliferative response and renal carcinogenesis in Wistar rats. Mol. Cell. Biochem. 2005, 271, 1-11. [CrossRef] [PubMed]

32. Aimvijarn, P.; Palipoch, S.; Okada, S.; Suwannalert, P. Thai water lily extract induces B16 melanoma cell apoptosis and inhibits cellular invasion through the role of cellular oxidants. Asian Pac. J. Cancer Prev. 2018, 19, 149-153. [PubMed]

33. Zhou, L.; Xia, M.; Wang, L.; Mao, H. Toxic effect of perfluorooctanoic acid (PFOA) on germination and seedling growth of wheat (Triticum aestivum L.). Chemosphere 2016, 159, 420-425. [CrossRef] [PubMed] 
34. Tăbăcaru, A.; Dediu Botezatu, A.V.; Horincar, G.; Furdui, B.; Dinică, R.M. Green Accelerated Synthesis, Antimicrobial Activity and Seed Germination Test of Quaternary Ammonium Salts of 1,2-bis(4-pyridyl)ethane. Molecules 2019, 24, 2424. [CrossRef] [PubMed]

35. Palmieri, M.J.; Luberb, J.; Andrade-Vieira, L.F.; Davide, L.C. Cytotoxic and phytotoxic effects of the main chemical components of spent pot-liner: A comparative approach. Mutat. Res. 2014, 763, 30-35. [CrossRef] [PubMed]

36. Gordaliza, M. Natural products as leads to anticancer drugs. Clin. Transl. Oncol. 2007, 9, 767-776. [CrossRef]

37. Samaranayake, Y.H.; Cheung, B.P.K.; Wang, Y.; Yau, J.Y.Y.; Yeung, K.W.S.; Samaranayake, L.P. Fluconazole resistance in Candida glabrata is associated with increased bud formation and metallothionein production. J. Med. Microbiol. 2013, 62, 303-318. [CrossRef]

38. Brunke, S.; Hube, B. Two unlike cousins: Candida albicans and C. glabrata infection strategies. Cell. Microbiol. 2013, 15, 701-708. [CrossRef]

39. Seleem, D.; Pardi, V.; Murata, R.M. Review of flavonoids: A diverse group of natural compounds with anti-Candida albicans activity in vitro. Arch. Oral Biol. 2017, 76, 76-83. [CrossRef]

40. Fort, R.S.; Barnech, J.M.T.; Dourron, J.; Colazzo, M.; Aguirre-Crespo, F.J.; Duhagon, M.A.; Álvarez, G. Isolation and Structural Characterization of Bioactive Molecules on Prostate Cancer from Mayan Traditional Medicinal Plants. Pharmaceuticals 2018, 11, 78. [CrossRef]

41. Kapinova, A.; Stefanicka, P.; Kubatka, P.; Zubor, P.; Uramova, S.; Kello, M.; Mojzis, J.; Blahutova, D.; Qaradakhi, T.; Zulli, A.; et al. Are plant-based functional foods better choice against cancer than single phytochemicals? A critical review of current breast cancer research. Biomed. Pharmacother. 2017, 96, 1465-1477. [CrossRef] [PubMed]

42. Ashidi, J.S.; Houghton, P.J.; Hylands, P.J.; Efferth, T. Ethnobotanical survey and cytotoxicity testing of plants of South-western Nigeria used to treat cancer, with isolation of cytotoxic constituents from Cajanus cajan Millsp. leaves. J. Ethnopharmacol. 2010, 28, 501-512. [CrossRef] [PubMed]

43. Zhao, Z.; Jin, G.; Ge, Y.; Guo, Z. Naringenin inhibits migration of breast cancer cells via inflammatory and apoptosis cell signaling pathways. Inflammopharmacology 2019, 27, 1021-1036. [CrossRef] [PubMed]

44. Tayeh, Z.; Ofir, R. Asteriscus graveolens Extract in Combination with Cisplatin/Etoposide/Doxorubicin Suppresses Lymphoma Cell Growth through Induction of Caspase-3 Dependent Apoptosis. Int. J. Mol. Sci. 2018, 19, 2219. [CrossRef]

45. Wang, X.; Yang, M.; Qian, J.; Xu, W.; Wang, J.; Hou, G.; Ji, L.; Suo, L. Sequentially self-assembled polysaccharide-based nanocomplexes for combined chemotherapy and photodynamic therapy of breast cancer. Carbohydr. Polym. 2019, 203, 203-213. [CrossRef]

46. Fernandes, R.S.; Silva, J.O.; Seabra, H.A.; Oliveira, M.S.; Carregal, V.M.; Vilela, J.M.C.; Andrade, M.S.; Townsend, D.M.; Colletti, P.M.; Leite, E.A.; et al. $\alpha$ - Tocopherol succinate loaded nanostructed lipid carriers improves antitumor activity of doxorubicin in breast cancer models in vivo. Biomed. Pharmacother. 2018, 103, 1348-1354. [CrossRef]

47. Jiang, G.; Liu, J.; Ren, B.; Zhang, L.; Owusu, L.; Liu, L.; Zhang, J.; Tang, Y.; Li, W. Anti-tumor and chemosensitization effects of Cryptotanshinone extracted from Salvia miltiorrhiza Bge. on ovarian cancer cells in vitro. J. Ethnopharmacol. 2017, 205, 33-40. [CrossRef]

48. Yu, J.; Ma, Y.; Drisko, J.; Chen, Q. Antitumor Activities of Rauwolfia vomitoria Extract and Potentiation of Carboplatin Effects Against Ovarian Cancer. Curr. Ther. Res. 2013, 75, 8-14. [CrossRef]

49. Tallarida, R.J. Quantitative Methods for Assessing Drug Synergism. Genes Cancer 2011, 2, $1003-1008$. [CrossRef]

50. Seo, E.J.; Klauck, S.M.; Efferth, T.; Panossian, A. Adaptogens in chemobrain (Part III): Antitoxic effects of plant extracts towards cancer chemotherapy-induced toxicity-Transcriptome-wide microarray analysis of neuroglia cells. Phytomedicine 2018, 56, 246-260. [CrossRef]

51. Chou, T.C. Drug Combination Studies and Their Synergy Quantification Using the Chou-Talalay Method. Cancer Res. 2010, 70. [CrossRef] [PubMed]

52. Kato, S.; Aoshima, H.; Saitoh, Y.; Miwa, N. Highly hydroxylated or $\gamma$-cyclodextrin-bicapped water-soluble derivative of fullerene: The antioxidant ability assessed by electron spin resonance method and $\beta$-carotene bleaching assay. Bioorg. Med. Chem. Lett. 2009, 19, 5293-5296. [CrossRef] [PubMed]

53. Martysiak-Żurowska, D.; Wenta, W. A comparison of ABTS and DPPH methods for assessing the total antioxidant capacity of human milk. Acta Sci. Pol. Technol. Aliment. 2012, 1, 83-89. 
54. Jones, A.; Pravadali-Cekic, S.; Dennis, G.R.; Bashir, R.; Mahon, P.J.; Shalliker, R.A. Ferric reducing antioxidant potential (FRAP) of antioxidants using reaction flow chromatography. Anal. Chim. Acta 2017, 967, 93-101. [CrossRef] [PubMed]

55. Yildirim, A.B.; Karakas, F.P.; Turker, A.U. In vitro antibacterial and antitumor activities of some medicinal plant extracts, growing in Turkey. Asian Pac. J. Trop. Med. 2012, 6, 616-624. [CrossRef]

56. Batool, R.; Kalsoom, A.; Akbar, I.; Arshad, N.; Jamil, N. Antilisterial Effect of Rosa damascena and Nymphaea alba in Mus musculus. BioMed Res. Int. 2018, 2018, 4543723. [CrossRef] [PubMed]

57. Rehman, S.; Ashfaq, U.A.; Ijaz, B.; Riazuddin, S. Anti-hepatitis C virus activity and synergistic effect of Nymphaea alba extracts and bioactive constituents in liver infected cells. Microb. Pathog. 2018, 121, 198-209. [CrossRef]

58. Bancirova, M. Changes of the Quercetin Absorption Spectra in Dependence on Solvent. Chem. J. 2015, 1, 31-34.

59. Seeram, N.; Lee, R.; Hardy, M.; Heber, D. Rapid large scale purification 541 of ellagitannins from pomegranate husk, a by-product of the commercial juice 542 industry. Sep. Purif. Technol. 2005, 41, 49-55. [CrossRef]

60. Abotaleb, M.; Samuel, S.M.; Varghese, E.; Varghese, S.; Kubatka, P.; Liskova, A.; Büsselberg, D. Flavonoids in Cancer and Apoptosis. Cancers 2019, 11, 28. [CrossRef]

61. Geethangili, M.; Ding, S.T. A Review of the Phytochemistry and Pharmacology of Phyllanthus urinaria L. Front. Pharmacol. 2018, 9, 1109. [CrossRef] [PubMed]

62. Khan, I.; Rahman, H.; Abd El-Salam, N.M.; Tawab, A.; Hussain, A.; Ali Khan, T.; Ali Khan, U.; Qasim, M.; Adnan, M.; Azizullah, A.; et al. Punica granatum peel extracts: HPLC fractionation and LC MS analysis to quest compounds having activity against multidrug resistant bacteria. BMC Complement. Altern. Med. 2017, 17, 247. [CrossRef]

63. Singh, A.; Chauhan, S.S.; Tripathi, V. Quinic acid attenuates oral cancer cell proliferation by downregulating cyclin D1 Expression and Akt signaling. Pharmacogn. Mag. 2018, 14, 14-19.

64. Inbathamizh, L.; Padmini, E. Quinic acid as a potent drug candidate for prostate cancer-A Comparative Pharmacokinetic Approach. Asian J. Pharm. Clin. Res. 2013, 6, 106-112.

65. Chung, I.M.; Kim, M.Y.; Park, W.H.; Moon, H.I. Quinic acid derivatives from Saussurea triangulata attenuates glutamate-induced neurotoxicity in primary cultured rat cortical cells. J. Enzym. Inhib. Med. Chem. 2009, 24, 188-191. [CrossRef]

66. Tanruean, K.; Poolprasert, P.; Kumla, J.; Suwannarach, N.; Lumyong, S. Bioactive compounds content and their biological properties of acetone extract of Cuscuta reflexa Roxb. grown on various host plants. Nat. Prod. Res. 2019, 33, 544-547. [CrossRef] [PubMed]

67. Kim, S.J.; Kim, M.C.; Um, J.Y.; Hong, S.H. The Beneficial Effect of Vanillic Acid on Ulcerative Colitis. Molecules 2010, 15, 7208-7217. [CrossRef]

68. Kumar, S.; Prahalathan, P.; Raja, B. Antihypertensive and antioxidant potential of vanillic acid, a phenolic compound in L-NAME-induced hypertensive rats: A dose-dependence study. Redox Rep. 2011, 16, 5. [CrossRef] [PubMed]

69. Qian, W.; Fu, Y.; Liu, M.; Wang, T.; Zhang, J.; Yang, M.; Sun, Z.; Li, X.; Li, Y. In Vitro Antibacterial Activity and Mechanism of Vanillic Acid against Carbapenem-Resistant Enterobacter cloacae. Antibiotic 2019, 8, 220. [CrossRef] [PubMed]

70. Tukiran; Mahmudah, F.; Hidayati, N.; Shimizu, K. A phenolic acid and its antioxidant activity from stem bark of chloroform fraction of Syzygium littorale (blume) amshoff (Myrtaceae). Molekul 2016, 11, 180-189. [CrossRef]

71. Rafiee, S.A.; Farhoosh, R.; Sharif, A. Antioxidant Activity of Gallic Acid as Affected by an Extra Carboxyl Group than Pyrogallol in Various Oxidative Environments. Eur. J. Lipid Sci. Technol. 2018, 120, 1800319. [CrossRef]

72. Chen, G.H.; Lin, Y.L.; Hsu, W.L.; Hsieh, S.K.; Tzen, J.T.C. Significant elevation of antiviral activity of strictinin from Puer tea after thermal degradation to ellagic acid and gallic acid. J. Food Drug Anal. 2015, 23, 116-123. [CrossRef] [PubMed]

73. Li, S.; Ye, T.; Liang, L.; Liang, W.; Jian, P.; Zhou, K.; Zhang, L. Anti-cancer activity of an ethyl-acetate extract of the fruits of Terminalia bellerica (Gaertn.) Roxb. through an apoptotic signaling pathway in vitro. J. Tradit. Chin. Med. Sci. 2018, 5, 370-379. [CrossRef]

74. Lipińska, L.; Klewicka, E.; Sójka, M. Structure, occurrence and biological activity of ellagitannins: A general review. Acta Sci. Pol. Technol. Aliment. 2014, 13, 289-299. [CrossRef] [PubMed] 
75. Xu, R.; Kang, Q.; Ren, J.; Li, Z.; Xu, X. Antitumor Molecular Mechanism of Chlorogenic Acid on Inducting Genes GSK-3 $\beta$ and APC and Inhibiting Gene $\beta$-Catenin. J. Anal. Methods Chem. 2013, 2013, 951319. [CrossRef] [PubMed]

76. Gil, M.; Wianowska, D. Chlorogenic acids-Their properties, occurrence and analysis. Ann. Univ. Mariae Curie Skłodowska Sect. AA Chem. 2017, 72, 61. [CrossRef]

77. Jia, L.; Jin, H.; Zhou, J.; Chen, J.; Lu, Y.; Ming, Y.; Yu, Y. A potential anti-tumor herbal medicine, Corilagin, inhibits ovarian cancer cell growth through blocking the TGF- $\beta$ signaling pathways. BMC Complement. Altern. Med. 2013, 13, 33. [CrossRef] [PubMed]

78. Moreira, J.; Klein-Junior, L.C.; Filho, V.C.; De Campos Buzii, F. Anti-hyperalgesic activity of corilagin, a tannin isolated from Phyllanthusniruri L. (Euphorbiaceae). J. Ethnopharmacol. 2013, 146, 318-323. [CrossRef]

79. Taofiq, O.; Sandrina, A.H.; Calhelha, R.C.; Fernandes, I.P.; Alves, M.J.; Barros, L.; González-Paramás, A.M.; Ferreira, I.C.F.R.; Barreiro, M.F. Phenolic acids, cinnamic acid, and ergosterol as cosmeceutical ingredients: Stabilization by microencapsulation to ensure sustained bioactivity. Microchem. J. 2019, 147, 469-477. [CrossRef]

80. Lou, W.; Chen, Y.; Ma, H.; Liang, G.; Liu, B. Antioxidant and a-amylase inhibitory activities of tannic acid. J. Food Sci. Technol. 2018, 55, 3640-3646. [CrossRef]

81. Gulcin, I.; Huyut, Z.; Elmastas, M.; Aboul-Enein, H.Y. Radical scavenging and antioxidant activity of tannic acid. Arab. J. Chem. 2010, 3, 43-53. [CrossRef]

82. Zielińska, D.; Szawara-Nowak, D.; Zieliński, H. Determination of the Antioxidant Activity of Rutin and Its Contribution to the Antioxidant Capacity of Diversifed Buckwheat Origin Material By Updated Analytical Strategies. Pol. J. Food Nutr. Sci. 2010, 60, 315-321.

83. Abarikwu, S.O.; Olufemi, P.D.; Lawrence, C.J.; Wekere, F.C.; Ochulor, A.C.; Barikuma, A.M. Rutin, an antioxidant flavonoid, induces glutathione and glutathione peroxidase activities to protect against ethanol effects in cadmium-induced oxidative stress in the testis of adult rats. Andrologia 2017, 49, e12696. [CrossRef] [PubMed]

84. Abid, M.; Yaich, H.; Cheikhrouhou, S.; Khemakhem, I.; Bouaziz, M.; Attia, H.; Ayadi, M.A. Antioxidant properties and phenolic profile characterization by LC-MS/MS of selected Tunisian pomegranate peels. J. Food Sci. Technol. 2017, 54, 2890-2901. [CrossRef]

85. Yin, P.; Yang, L.; Xue, Q.; Yu, M.; Yao, F.; Sun, L.; Liu, Y. Identification and inhibitory activities of ellagic acid and kaempferol-derivatives from Mongolian oak cups against a-glucosidase, a-amylase and protein glycation linked to type II diabetes and its complications and their influence on HepG2 cells'viability. Arab. J. Chem. 2018, 11, 1247-1259. [CrossRef]

86. Ahmed, S.; Khan, H.; Fratantonio, D.; Hasan, M.M.; Sharifi, S.; Fathi, N.; Ullah, H.; Rastrelli, L. Apoptosis induced by luteolin in breast cancer: Mechanistic and therapeutic perspectives. Phytomedicine 2019, 59, 152883. [CrossRef]

87. Kim, K.J.; Park, S.U. A recent overview on the biological and pharmacological activities of ferulic acid. EXCLI J. 2019, 18, 132-138.

88. Chahar, M.K.; Sharma, N.; Dobhal, M.P.; Joshi, Y.C. Flavonoids: A versatile source of anticancer drugs. Pharmacogn. Rev. 2011, 5, 1-12.

89. Lam, K.Y.; Ling, A.P.; Koh, R.Y.; Wong, Y.P.; Say, Y.H. A Review on Medicinal Properties of Orientin. Adv. Pharmacol. Sci. 2016, 2016, 4104595. [CrossRef]

90. Liu, D.; Xie, B.; Dong, C.; Liu, G.; Hu, D.; Qin, Y.; Li, H.; Liu, H. Effect of fertilizer prepared from human feces and straw on germination, growth and development of wheat. Acta Astronaut. 2018, 1-30. [CrossRef]

91. Sturm, D.J.; Kunz, C.; Gerhards, R. Inhibitory effects of cover crop mulch on germination and growth of Stellaria media (L.) Vill. Chenopodium album L. and Matricaria chamomilla L. Crop Prot. 2016, 90, 125-131. [CrossRef]

92. Arendrup, M.C.; Cuenca-Estrella, M.; Lass-Flörl, C.; Hope, W. EUCAST technical note on the EUCAST definitive document EDef 7.2: Method for the determination of broth dilution minimum inhibitory concentrations of antifungal agents for yeasts EDef 7.2 (EUCAST-AFST). Clin. Microbiol. Infect. 2012, 18, E246-E247. [CrossRef] [PubMed]

93. Cardoso, J.M.S.; Guerreiro, S.I.; Lourenço, A.; Alves, M.M.; Montemor, M.F.; Mira, N.P.; Leitão, J.H.; Carvalho, M.F.N.N. Ag(I) camphorimine complexes with antimicrobial activity towards clinically important bacteria and species of the Candida genus. PLoS ONE 2017, 12, e0177355. [CrossRef] [PubMed] 
94. Nair, S.K.; Verma, A.; Thomas, T.J.; Chou, T.C.; Gallo, M.A.; Shirahata, A.; Thomas, T. Synergistic Apoptosis of MCF-7 Breast Cancer Cells by 2-Methoxyestradiol and Bis(ethyl)norspermine. Cancer Lett. 2007, 250, 311-322. [CrossRef] [PubMed]

95. Liu, Z.; Li, H.; Fan, Y.; Liu, Y.; Man, S.; Yu, P.; Gao, W. Combination treatment with Rhizoma Paridis and Rhizoma Curcuma longa extracts and 10-hydroxycamptothecin enhances the antitumor effect in H22 tumor model by increasing the plasma concentration. Biomed. Pharmacother. 2016, 83, 627-634. [CrossRef] [PubMed]

96. Athamena, S.; Chalghem, I.; Kassah-Laouar, A.; Laroui, S.; Khebri, S. Activité anti-oxydante et antimicrobienne d'extraits de Cuminum cyminum L. Leban. Sci. J. 2010, 11, 69-81.

97. Thaipong, K.; Boonprakob, U.; Crosby, K.; Cisneros-Zevallos, L.; Byrne, D.H. Comparison of ABTS, DPPH, FRAP, and ORAC assays for estimating antioxidant activity from guava fruit extracts. J. Food Compos. Anal. 2006, 19, 669-675. [CrossRef]

(C) 2019 by the authors. Licensee MDPI, Basel, Switzerland. This article is an open access article distributed under the terms and conditions of the Creative Commons Attribution (CC BY) license (http://creativecommons.org/licenses/by/4.0/). 